State-of-the-Art Review Articles

\title{
Greek syntax
}

\section{A principles and parameters perspective ${ }^{\star}$}

\author{
Artemis Alexiadou and Elena Anagnostopoulou \\ U. Potsdam/AUTH / U. Crete
}

The last decades have seen a particular growth of syntactic studies in Greek from different aspects within the principles and parameters framework. In this article we present an overview of the main areas of investigation.

Reasons of space prevent us from an exhaustive presentation of all the issues examined in the literature. In what follows, we concentrate mainly on topics that have attracted a lot of attention in the more recent literature (see also the presentation in Theophanopoulou-Kontou 1994; Drachman et al. 1997; Alexiadou, Horrocks \& Stavrou 1999).

Keywords: clitic-doubling, clitic left dislocation, clitic placement, person case constraint, modals, functional projections, discourse configurationality, anaphors, adverbs, negation, subjunctive, control, raising, nominalisation, $\mathrm{V}$-movement, determiner, spreading, relative clauses, unaccusatives, prepositional phrases

\section{Clause structure}

Within the Principles and Parameters framework, numerous proposals have been made concerning the architecture of the inflectional system, in particular the inventory and order of functional projections dominating VP. More recent work, following Pollock (1989) and Ouhalla (1988), suggests that the clause structure is more richly articulated than previously assumed. For instance, on the basis of the relative positions of the verb with respect to the marker of sentential negation in ( $1 \mathrm{a}-\mathrm{b})$, it was argued that IP should be decomposed into the components T (tense) and AGR (agreement) (cf. Chomsky 1995: Ch.3, Belletti 1990 among others). 
(1) a. Jean ne mangeait pas souvent de chocolat. Jean NEG ate not often of chocolate 'Jean did not often eat chocolate.'

b. Ne pas manger souvent de chocolat... NEG not eat.INF often of chocolate

The linear sequence of the inflectional morphemes is standardly taken to correspond to the hierarchical ordering of the functional nodes (cf. Baker 1988) on the verb. Hence INFL was broken down into its functional components AGR, Tense.

It has been claimed that severed functional categories are instantiated in Greek, since they form part of the morphology of the Greek verb (see Rivero 1994; Tsimpli 1990; Philippaki-Warburton 1989, 1998; Drachman 1991, to mention a few). Consider the paradigm below:

(2) $\gamma \rho a ́ \varphi \omega$

$\gamma$ raf-o

write-SG

(3) a. $\quad \gamma \rho \alpha ́ \alpha \alpha \mu \varepsilon$

grap-s-ame

write-PERF.PAST.1PL

b. $\quad$ $\rho \dot{\varphi} \varphi \alpha \mu \varepsilon$

rraf-ame

write-IMP.PAST.1PL

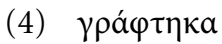

$\gamma$ raf-tik-a

write-PASS.PAST.1sG

(5) $v \alpha \quad \gamma \rho a ́ \varphi \omega$

na $\gamma$ raf-o

SUBJ write-1SG

As is clear from (2)-(5) verbs in Greek inflect for voice (active vs. non-active), aspect (perfective vs. imperfective), person and number agreement. Though the arguments for splitting tense from agreement are not so straightforward in Greek (see Rivero 1994; Iatridou 1993; Horrocks 1994; Philippaki-Warburton \& Spyropoulos 1999b; Joseph \& Smirniotopoulos 1993), given the ordering of morphemes in the paradigm, (6) below is taken to represent the functional categories present in the extended projection of the Greek verb:

(6) AGR $>$ TP $>$ AspectP $>$ VoiceP $>$ VP 
The modal marker na precedes all inflectional material. Na has been analyzed as a subjunctive mood marker (see Philippaki-Warburton \& Veloudis 1984; Philippaki-Warburton 1994a; Rivero 1994) or a subjunctive complementizer (see Tsoulas 1993; Agouraki 1991). In any event, it precedes the TP projection.

In addition, Negation has been added to the inventory of functional heads and its properties have been extensively discussed (see Giannakidou 1997; Klidi 1994). Greek has two negation particles: $\delta e n$ which co-occurs with indicative forms and min which co-occurs with subjunctive forms, i.e. those involving na:

(7) a. $\delta \varepsilon v \theta \varepsilon ́ \lambda \omega$

Sen $\theta$ elo

NEG want-1sG

'I do not want'

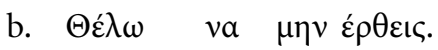

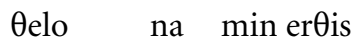

want-1sG SUBJ NEG come-2sG

'I do not want you to come.'

An issue that has attracted a great deal of attention in the literature is whether or not these two negation particles occupy the same slot in the clause structure. Another point of controversy concerns the issue whether $\mathrm{Neg}^{\circ}$ precedes $\mathrm{Mood}^{\circ}$ or vice versa, with reference also to the fact that imperatives in Greek cannot be negated (Rivero 1994; Drachman 1991; Philippaki-Warburton 1998 among others).

\section{Topic and Focus: (Discourse) configurationality}

It is well-known that Greek is a language with a certain freedom of word order which is reminiscent of the patterns found in non-configurational languages. This has been related to case (Catsimali 1990) or to the presence of object clitics and subject agreement (Alexiadou \& Anagnostopoulou 1999c). In fact, Catsimali (1990) has argued that Greek is non-configurational in the sense of Hale (1983) and Kiss (1987), but this view is not generally accepted in the literature on Greek (see Horrocks 1994 for a thorough discussion of the issue).

It has also been noted that the information structure of a given sentence is reflected in the manner in which phrases are structured in the sentence, and moreover that it is crucially related to its intonation structure. Thus Greek has been argued to bear a certain resemblance to discourse configurational languages, as the different word order patterns convey different information (Philippaki-Warburton 1985; Agouraki 1990, 1993; Tsimpli 1995; Alexiadou \& 
Anagnostopoulou 1995; Alexiadou 1999a, among others). As these authors point out, a basic fact about Greek is that postverbal subjects are not equivalent to preverbal subjects from the point of view of information structure, i.e. they tend to constitute 'new' information. Consider the sentences in (8). Once the DP 'a letter' has been introduced in the discourse, i.e. it conveys 'old' information, it can no longer occupy a postverbal position:

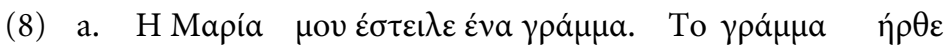
i maria mu estile ena $\gamma$ rama to $\gamma$ rama irӨe Mary-Nom me sent a letter-ACC the letter-NOM arrived

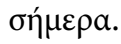

simera

today

'Mary sent me a letter. The letter arrived today.'

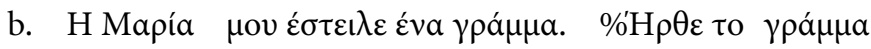
i maria mu estile ena $\gamma \mathrm{rama} \%$ irӨe to $\gamma \mathrm{rama}$ Mary-Nom me sent a letter-ACC arrived the letter-Nom

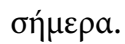
simera today 'Mary sent me a letter. The letter arrived today.'

On the other hand, tests diagnosing the 'new' information status of a certain DP show that standard answers to the question 'what happened?' in Greek involve inverted subject orders:

- what happened?

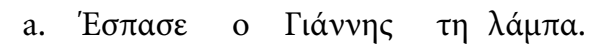
espase o janis ti lamba broke-3sg the John-Nom the lamp-ACC 'John broke the lamp.'

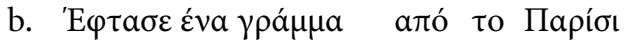
eftase ena $\gamma$ rama apo to parisi arrived a letter-NOM from the Paris-ACC 'A letter arrived from Paris.'

If one relates notions such as 'old' and 'new information' to the grammatical notions of topic and focus which are grammatically encoded in sentence grammar, then preverbal subjects behave like topics, while postverbal subjects are part of the focus. In fact, Alexiadou \& Anagnostopoulou (1998a) have 
argued in detail that preverbal subjects behave like Clitic Left Dislocated (CLLDed) elements directly merged in an A-position (see also Tsimpli 1995, and Philippaki-Warburton 1985; and for a different view according to which the SpecIP position has mixed A/Ā properties, see Horrocks 1994).

This behavior of subjects correlates with V-movement. Alexiadou \& Anagnostopoulou (1998a) proposed that in all pro-drop languages V-raising to I takes place in order to check its EPP feature. On the other hand, PhilippakiWarburton \& Spyropoulos (1999b) argue that SpecTP is occupied by subject clitic associated with pro in VP, checking T's EPP feature.

In Greek focussed material appears either in the left periphery or in situ, as is shown in the examples below, where the subject John is focused.

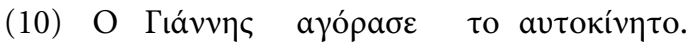

$\mathrm{O}$ JANIS ayorase to aftokinito

the John-NOM bought-3sg the car-ACC

'John bought the car.'

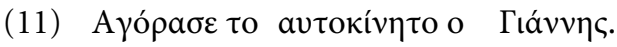
ayorase to aftokinito $\mathrm{O}$ JANIS bought the car-ACC the John-NOM 'John bought the car.'

As Tsimpli (1995) convincingly argues, in (10) the subject is moved overtly to the specifier of a focus projection. According to Tsimpli, (10) behaves unlike a CLLD-ed structure (see Section 4) and shows all the properties of a construction involving operator-movement. For instance, no resumptive pronoun can be present, and the sentence can have only one focused element. As is well known (Cinque 1990), in CLLD structures the presence of a clitic is necessary. Moreover, the sentence can have more than one CLLD-ed elements:

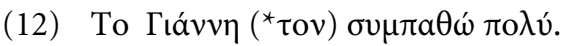

TO JANI ( ${ }^{*}$ ton) simba日o poli

the John him like-1sg much

'It is John that I like a lot.'

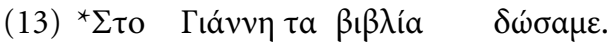

STO JANI TA VIVLIA $\delta$ osame

to.the John the books-ACC gave-1PL

'It is John we gave the books to.'

Furthermore, Tsimpli points out that in main clauses, focused constituents interact with wh-phrases in an interesting way. She argues that main clauses 
contain only one specifier position in which wh- and focused phrases could land. As a result, the two compete for the same position. Sentences containing both a focused phrase and a wh-phrase are ungrammatical:

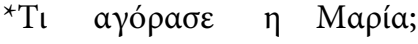
ti ayorase I MARIA
what bought-3sg the Mary-Nom
'What did Mary buy?'

This does not hold if the wh-phrase and the focused element are situated in different clauses (15), so that the scope domain of the two does not coincide. In case the two domains coincide, ungrammaticality arises even if the two are in different clauses (16):

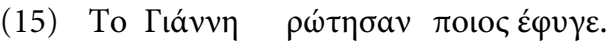
ton JANI rotisan pjos efije the John-ACC asked-3PL who left-3sG 'It was John that they asked who left.'

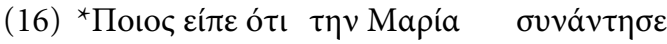
pjos ipe oti tin MARIA sinandise who said that the Mary-ACC met-3sg 'Who said that s/he met Mary?'

In (16) the focused phrase must raise to the matrix clause at LF. This gives rise to a situation where the focused phrase and the wh-phrase have identical scope domains.

According to Tsimpli, in (11) the focused DP raises to Focus at LF. On the other hand, Alexiadou (1999b), building on Kiss (1996), points out that preverbal foci are not equivalent to postverbal ones: while in (10) the subject receives a contrastive or narrow-focus reading, 'it was John and not Paul', in (11) the subject simply receives 'new' information focus. In (11) the subject is situated VP-internally and does not need to raise to FocusP; the Focus projection in the left periphery 'licenses' contrastive focus only. That the subject is situated VP-internally and that VOS orders are derived via leftward movement of the object is supported by data such as the ones in (17) below:

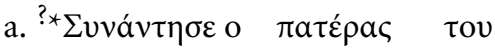

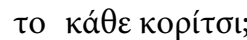 sinandise $\mathrm{o}$ pateras $\mathrm{tu}_{\mathrm{i}} \quad$ [to kaӨe koritsi $]_{\mathrm{i}}$ met-3sg the father-NOM CL-GEN the each girl 


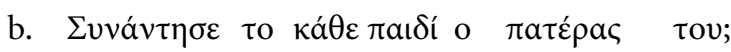
sinandise [to kaقe pe $\delta \mathrm{i}]_{\mathrm{i}} \mathrm{o}$ pateras $\mathrm{tu}_{\mathrm{i}}$ met-3sG the each child the father-NOM CL-GEN 'Did each father meet his child?'

According to a number of native speakers, (17a) is ungrammatical since it fails to meet the c-command requirement on the pronominal binding of the possessive (or, alternatively, as a WCO violation due to the bijection principle). ${ }^{1}$ On the other hand, in (17b) the object has been scrambled to the left and thus c-commands the subject possessive pronoun (or, the WCO effect is obviated because this is a case of A-scrambling which feeds variable binding).

According to Tsimpli, preverbal focussed constituents need to be adjacent to the verb. However, this constitutes an issue of controversy. Giannakidou (1997) points out that examples such as the following are completely grammatical:

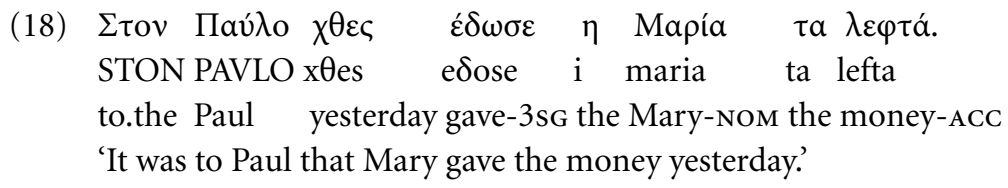

\section{Adverbs}

In the recent literature, the research on the type and content of functional projections which constitute the clausal architecture runs in parallel with certain hypotheses concerning adverb placement. According to these views, the presence of certain types of adverbs within the verbal clause constitutes evidence for the presence of certain functional projections. Hence recent work on the syntax of adverbs has put forth the hypothesis that adverbial phrases are the unique specifiers of distinct functional projections (see Alexiadou 1997; Cinque 1999). This hypothesis is partly embedded within the framework of Antisymmetry (Kayne 1994), and crucially builds on the transparent semantic relation that can be observed cross-linguistically, and is moreover suggestive of a specifier-head relation between adverbs and functional heads. For Greek this has been extensively discussed in Alexiadou (1997). The strings below show that the different adverbs and the different functional heads have a systematic oneto-one relation: 


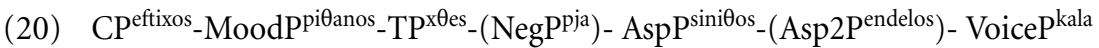
fortunately probably yesterday anymore usually completely well

Xydopoulos (1996), on the other hand, building on Chomsky (1995) and concentrating on the semantic and syntactic properties of temporal and aspectual adverbs, proposes that such adverbs are 'second' specifiers of the respective functional projections.

\section{Clitics}

The syntax of clitics is an area that has received much attention in the literature on Greek and has given rise to interesting theoretical results (see the overview in Drachman 1997).

Greek does not have clitics equivalent to Romance ne, $y$, en. Greek clitics are the weak/short/non-emphatic forms of the personal pronouns of the first, second and third person singular and plural, encoding features of direct and indirect object and the possessor (with nouns - see Section 5.3 for possessive clitics), the first manifesting accusative case and the latter two genitive case (see 21), at least in Standard Greek:

(21) SG GEN

$$
\begin{aligned}
& \mathrm{mu} \text { 'to me'/'my' } \\
& \text { su 'to you'/'your' } \\
& \text { tu/tis/tu 'to him/her/it' 'his/hers/its' }
\end{aligned}
$$

SG ACC

me 'me'

se 'you'

ton/tin/ton 'him/her/it'

PL GEN mas 'to us/'ours' sas 'to you/'yours' tus 'to them' 'theirs'

PL ACC mas 'us' sas 'you' tus/tis/ta 'them'

Some linguists assume that the person and number indication of the verbal ending identifying pro 'corresponds' to a nominative clitic (Philippaki-Warburton 1987 who follows Safir 1985; Alexiadou \& Anagnostopoulou 1998a following Sportiche 1992). True nominative clitics have been also argued to be present in the language (see Joseph 1994).

(22) Ná Toc.

na tos

here CL-NOM

'Here he is.' 
Clitics precede the finite verb forms but are enclitic on (non-finite) gerunds and the imperative (similarly to Spanish, Italian, French and Catalan) although there is dialect variation (Rivero \& Terzi 1995; Terzi 1999a), allowing for enclitics with both finite and non-finite verbs.
a. то $\beta \lambda \varepsilon \dot{\varepsilon} \pi \omega$
to vlepo
it see-1sG
'I see it.'

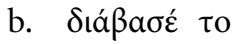
Sjavase to
read-2sg it
'Read it!'

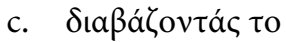
Sjavazondas to
reading CL-ACC
'reading it'

The relative order of the preverbal clitics is strictly indirect object-direct object but there is no strict order between enclitics:
a. Mov to $\varepsilon \delta \omega \sigma \varepsilon$.
$\mathrm{mu}$ to edose
CL-GEN CL-ACC gave-3sG
'He/she gave it to me.'

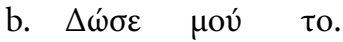
Sose $\mathrm{mu}$ to
give-2SG CL-GEN CL-ACC
'Give it to me.'
c. $\Delta \omega ́ \sigma \varepsilon$ tó $\mu \mathrm{ov}$.
give-2SG CL-ACC CL-GEN
'Give it to me.'

Clitic placement has been investigated by a number of linguists including Rivero (1994), Drachman (1991), Philippaki-Warburton (1994b), Terzi (1992), Hegarty (1999), Terzi (1996, 1999b), Anagnostopoulou (1999b), PhilippakiWarburton \& Spyropoulos (1999a).

Rivero (1994), Drachman (1991), Terzi (1992), Philippaki-Warburton (1994b) and Hegarty (1999) offer alternative explanations to account for the position of clitics as well as the environments in which proclisis and enclisis occur. 
Terzi (1992) and Rivero (1994) argue that in finite clauses clitics left adjoin to the inflectional head to which the verb raises (Kayne 1989, 1991). Rivero (1994) develops an interesting analysis for the distribution of clitics in Imperatives which is based on the view that the verb undergoes head movement to $\mathrm{C}$ of the $\bar{A}$ type which is triggered by illocutionary features in C (see also Rivero \& Terzi 1995). It is proposed that this movement is blocked by Negation, which is assumed to be an operator head under a version of Relativized Minimality (Rizzi 1990) on head movement which is relativized to the A vs. $\bar{A}$ status of intervening heads (see also Terzi 1992 for an approach according to which the Head Movement Constraint is relativized to the $A / \bar{A}$ status of intervening heads). This analysis captures the correlation between enclisis and absence of negation in imperatives; for an alternative analysis see Philippaki-Warburton (1998). For gerunds, Rivero (1994) argues that they move to Mood in order to pick up the gerundive affix resulting in enclisis, but they can co-occur with negation which is higher than Mood (Rivero 1994; Terzi 1992 but see Zanuttini 1991 for Romance). Philippaki-Warburton (1994b) argues that when the clitics are proclitic, they deprive the category that follows them of its specifier. If they are enclitic, they are themselves generated in the head of a projection which lacks its specifier. Drachman (1994), on the other hand, capitalizes on the availability of projecting two Agreement projections (Cardinaletti \& Roberts 1991) in the clause structure. Clitics are situated in AGR1. In proclisis, the verb moves to AGR2, while in enclicis the clitic is situated in AGR2 and the verbal element moves to Mood.

Terzi (1996) investigates the properties of the functional head to which clitics adjoin from the point of view of Kayne's (1994) antisymmetry framework; she argues that clitics adjoin to a functional head F, which is a featureless functional head in finite clauses-contra Kayne $(1989,1991)$ - while it is T in gerunds and imperatives. Terzi (1999b) explores an LCA line of analysis to account for the puzzle concerning the rigid vs. free ordering of clitics in proclisis and enclisis respectively. She proposes that the LCA makes two options available for the manner in which more than one clitic adjoins in the clausal structure: either (i) each clitic adjoins to a different functional head (25), or (ii) one clitic adjoins to the other (26): 
$(25)$

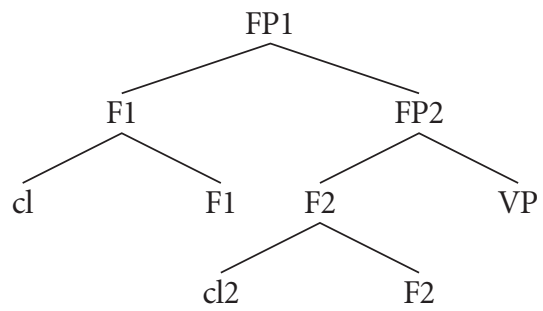

(26)

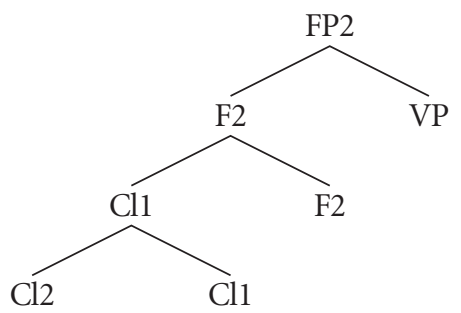

In (25) FP1 is an empty functional head, a placeholder for clitics, while FP2 is T. In (26), on the other hand, FP2 is T. Terzi proposes that Greek double object clitics instantiate both the first and the second option, while in Romance only the second option is possible, i.e. clitics cluster under the same head T. In contexts of enclisis, the accusative $>$ dative order results from a derivation in which the verb incorporates into the accusative clitic in (25), and the two move as a complex higher up, while the dative $>$ accusative order results from a configuration in which the verb adjoins to $\mathrm{Cl} 2$ in (26) and the whole complex moves higher up. Assuming that in Romance only the second option is possible, the order of clitics is not altered in contexts of enclisis.

Hegarty (1999) addresses the problem of different clitic placement in proclitic and enclitic clauses as well as clitic ordering within the Minimalist framework, more specifically the version of checking theory assumed in Chomsky (1993). He argues that the alternation between proclisis and enclisis in Greek (similarly to Italian and Spanish) arises from the possibility of dissociating the checking of $\mathrm{N}$-features on nominals against a functional head from the checking of $\mathrm{V}$-features by the verb; this is tied to the null subject property of the language.

Anagnostopoulou (1999b) also looks at clitic placement from the perspective of checking theory, but the general framework assumed is the one outlined in Chomsky (1995) and the focus of interest is shifted from the enclisis vs. proclisis issue to the problem of clitic ordering in connection with a constraint known in the literature as me-lui or Person-Case constraint (Perlmutter 1971; Kayne 1975; Bonet 1991; Ormazabal \& Romero 1998). This constraint is found 
in a number of languages with clitics, weak pronouns and agreement markers including Spanish, Italian, Catalan, French, Greek, Arabic, Swiss German, Basque and Georgian (Bonet 1994 claims that it is universal) and it is formulated in (27) and illustrated in (28) for Greek:

(27) Person Case Constraint

Context: Ditransitives with phonologically weak direct and indirect objects

Observation: If a direct and an indirect object co-occur, the direct object has to be 3rd person.

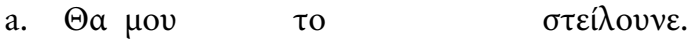
$\theta \mathrm{a} \mathrm{mu}$ to stilune
FUT CL-GEN.1SG CL-ACC.3SG.NEUT send-3PL
'They will send it to me.'

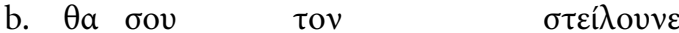
$\theta \mathrm{a}$ su ton stilune
FUT CL-GEN.2SG CL-ACC.3sG.MASC send-3PL
'They will send him to you.'

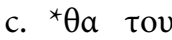
$\theta \mathrm{a}$ tu me stilune
FUT CL-GEN.3SG.NEUT/MASC CL-ACC.1SG send-3PL
'They will send me to him.'
$\mu \varepsilon \quad \sigma \tau \varepsilon \dot{\lambda} \lambda$ ovve
d. ${ }^{*} \theta \alpha$ tov $\quad \sigma \varepsilon \quad \sigma \tau \varepsilon i ́ \lambda o u v \varepsilon$
$\theta \mathrm{a}$ tu se stilune
FUT CL-GEN.3sG.MASC CL-ACC.2SG send-3PL
'They will send you to him.'

Anagnostopoulou proposes that, in the constructions where a 3rd person restriction arises, person features are checked separately from number features (Taraldsen 1995; Chomsky 1998 for Icelandic nominative objects) on v. The proposed derivation is given in (29): 


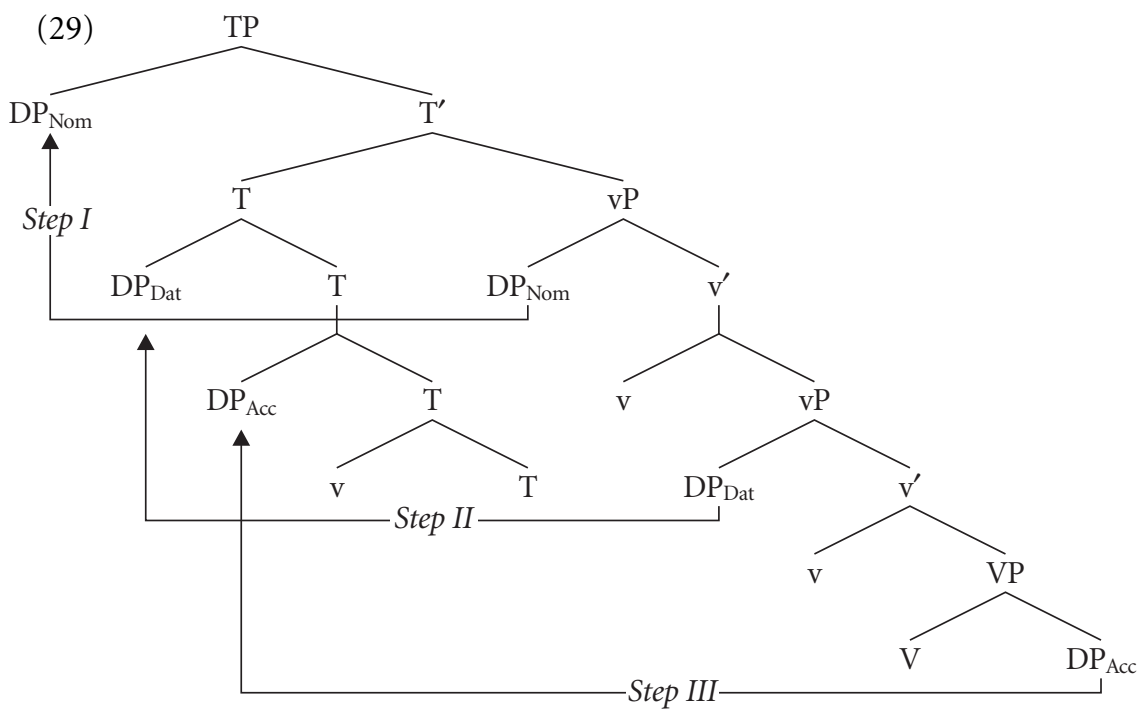

Crucial for this analysis is a syntax for double object constructions according to which (i) indirect objects and direct objects $\operatorname{check} \varphi$-features against the same head v, (ii) the indirect object is generated higher than the direct object (contra Catsimali 1990; see Section 10) and (iii) the indirect object moves to v before the dative in a derivation that conforms with featural cyclicity (Richards 1997). Anagnostopoulou (1999b) argues that the rigid genitive-accusative order found in Greek directly reflects the order of movements in (29). Although this order is similar to orders found in Italian and Spanish, clitic ordering in Greek is the direct output of the syntactic derivation, unlike Romance where clitics are organized according to person features in the morphological component, as convincingly argued by Bonet (1991) (see also Joseph 1988 who points out that clitics can be thought of as morphological units).

The various approaches to clitic placement illustrated above attempt to highlight different aspects of the complex problem of clitics, their hosts and combinations and, therefore, they reach slightly different conclusions, in part also because they start from different theoretical considerations. For example, the LCA hypothesis (Kayne 1994) imposes certain restrictions that lead to the position that clitics adjoin to different functional heads, while the hypothesis that the core functional heads against which arguments check formal features are $\mathrm{v}$ and $\mathrm{T}$ (Chomsky 1995, 1998, 1999) leads one to the opposite position, at least under the assumption that formal feature checking is a trigger for clitic movement. ${ }^{2}$ Nevertheless, there is a growing consensus that the view that clitic placement is 
syntactic rather than morphological leads to interesting solutions to puzzles and captures non-trivial co-relations that would otherwise remain un-addressed. For a different view see Joseph \& Smirniotopoulos (1993); for evidence that the movement is syntactic see Philippaki-Warburton \& Spyropoulos (1999a).

Object clitics form a number of dependencies with full DPs, namely in (Clitic) Left Dislocation, Clitic Doubling:
a.

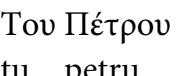
тo $\beta ı$ ß ío

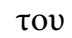
to
$\varepsilon ́ \delta \omega \sigma \alpha$.
CLLD
the Peter-Gen the book-ACC CL-GEN CL-ACC gave-1sG
'I gave Peter the book.'

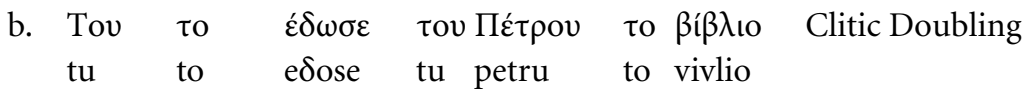
CL-Gen CL-ACC gave-3sg the Peter-Gen the book-ACC
$\eta$ Mapía.
i maria
the Mary-NOM
'Mary gave Peter the book.'

In addition, clitics may occur in wh-questions under certain conditions, i.e. when the wh-phrase is partitive or D(iscourse)-Linked (Theophanopoulou Kontou 1986-1987; Iatridou 1991):
a. Пotov

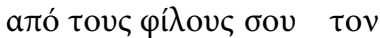

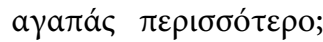
pjon
apo tus filus su ton ayapas perisotero
which-ACC of the friends yours CL-ACC love-2sG more?
'Which one of your friends do you love most?'

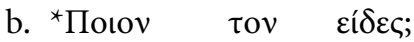
pjon ton ides
whom-ACC CL-ACC saw-2sG

CLLD has been discussed extensively in Philippaki Warburton (1987), Iatridou (1991), Agouraki (1993), Tsimpli (1990, 1995), Anagnostopoulou (1994, 1997), Schneider-Zioga (1993). Various aspects of the syntax of Clitic Doubling have been discussed in Drachman (1983), Fykias (1988), Philippaki-Warburton (1987), Agouraki (1993), Anagnostopoulou (1994, 1999b), Schneider-Zioga (1993), Alexiadou \& Anagnostopoulou (1997, 1999c) and Dimitriadis (1999). Clitics in interrogatives have been discussed in Theophanopoulou-Kontou (1986-1987), Iatridou (1991) and Anagnostopoulou (1994).

At a factual level, the discussion of CLLD and Clitic Doubling has been obscured by the fact that some further distinctions between closely related 
constructions are not always recognized. For example Alexiadou (1997) and Anagnostopoulou (1997) argue that CLLD differs from Hanging Topic Left Dislocation (HTLD) in Greek with respect to Case Connectedness which is present in the former but absent in the latter construction. On the other hand, Tsimpli $(1990,1995)$ does not distinguish between CLLD and HTLD and assumes that in Greek Left Dislocation, LDed DPs may always have default nominative Case, unlike focused DPs in Focus-fronting constructions. A related issue arises with respect to Clitic Doubling and Right Dislocation. Given that Greek is a language in which clitic doubling is not subject to Kayne's Generalization (1975) (Drachman 1983; Fykias 1988; Joseph 1988; Dimitriadis 1999; see Iatridou's 1991 point below), it is hard to distinguish between Clitic Doubling and Right Dislocation, unlike languages like, e.g. Spanish (see Anagnostopoulou 1994 for some arguments based on Jaeggli 1986, and Anagnostopoulou 1999b who argues basing herself on Zubizarreta 1998 and Alexiadou 1999a that Greek has genuine clitic doubling and not just right dislocation because it permits a doubled object DP to occur preceding a postverbal subject carrying the main stress of the sentence).

One line of approaches takes all or some of these constructions to have a uniform syntax. For example, Philippaki-Warburton (1987) proposes that CLLD and Clitic Doubling both involve a relationship between a clitic in argument position and a DP-adjunct in a left- or right-peripheral position (see also Aoun 1981; Hurtado 1984 for Romance and Baker 1996 for polysynthetic languages). A similar position is taken in Schneider-Zioga (1993) who argues following Iatridou (1991) for CLLD (see below) that CLLD and Clitic Doubling should be accounted for in terms of predication (see also Aoun 1999 for Lebanese Arabic). The "doubled DP" is not in a thematic position and is interpreted with respect to a complex predicate. In this analysis, the doubled element has the role of subject of predication, the phrase it is attached to is a complex predicate and the clitic-pro complex provides the open position, or the predicate variable. An analysis along these lines does not recognize the distinction between Clitic Doubling and Right Dislocation. A uniform account of Clitic Doubling and CLLD is also put forth in Agouraki (1993), but the specifics of the overall analysis are crucially different. In the spirit of Sportiche (1992), Agouraki (1993) proposes that clitics are functional heads heading their own projection and they may co-occur with full DPs in argument positions (Clitic Doubling). The doubled DPs may raise overtly to the specifier of the clitic head and from there they can move further on (CLLD). Agouraki points out that CLLD has mixed A/A properties, similarly to scrambling. She proposes to 
account for this similarity by postulating that the movement step of the DP to the clitic position has A properties (akin to an agreement process) while movement beyond this domain has A properties (cf. Mahajan 1990 for short-, medium- and long-distance scrambling, Sportiche 1992 who proposes to unify the syntax of clitic constructions and scrambling, and Alexiadou \& Anagnostopoulou 1997 who argue that the counterpart of short scrambling is clitic doubling substantiating Sportiche's claim with evidence from binding).

A different line is pursued in Iatridou (1991) and Anagnostopoulou (1994, 1997) who provide a number of arguments to show that Clitic Doubling and CLLD cannot be analysed on a par. Iatridou points out that the conditions under which Clitic Doubling and CLLD are licensed are not identical; for example there are languages that have CLLD but no Clitic Doubling (French, Italian), and there are languages in which Kayne's Generalization holds for Clitic Doubling but not for CLLD (Spanish). Anagnostopoulou (1994) further points out that while Clitic Doubling in Greek is only possible with discourse prominent DPs, CLLD is much more free: it may take place with DPs that are novel in discourse and can be used as topics in the sense of Reinhart (1982) (cf. Alexopoulou 1999 for extensive argumentation that CLLDed phrases, unlike clitic doubled DPs, express the information packaging notion of linkhood (Vallduvi 1992) understood in terms of non-monotone anaphora). Iatridou (1991) concludes that CLLD does not originate from a Clitic Doubling configuration and proposes that CLLD is a predication structure: the LDed DP is the subject of predication and it is base-generated in a position adjoined to the clause which forms the complex predicate; the open position necessary for the clause to function as a variable is provided by the cl-pro chain. According to Iatridou (1991) CLLD takes place with D(iscourse)-linked DPs (Pesetsky 1987), a fact which explains why clitics are possible with D-linked interrogatives: these do not have the syntax of questions but rather they involve CLLD of a D-linked wh-phrase. She further develops a derivational account of the selective island sensitivity property of CLLD which dispenses with the notion of referential chains argued for in Cinque (1990) (who modifies Rizzi 1990). Anagnostopoulou $(1994,1997)$ adopts Iatridou's analysis for CLLD and proposes further to unify CLLD with Contrastive Left Dislocation, a construction found in Germanic (German, Dutch, Icelandic, see the various contributions to Anagnostopoulou, van Riemsdijk \& Zwarts 1997). For Clitic Doubling, she maintains an analysis along the lines of Sportiche (1992) according to which clitics are markers for specificity (Spanish) or Prominence (Greek) on their associated DPs which are in argument position (see Anagnostopoulou \& Giannakidou 
1995 for a generalized treatment of doubling clitics cross-linguistically as markers for referentiality). Finally, Anagnostopoulou argues that wh-questions with clitics do not involve CLLD (contra Iatridou 1991) but rather the clitics "spell-out" a pronominal variable (Cinque 1990) licensed under referentiality.

It is striking, though by no means unexpected, that the literature which focuses on simple cliticization constructions for the most part adopts a movement approach to cliticization (cf. Kayne 1975, 1989, 1991) while the literature that is concerned with clitic dependencies and especially Clitic Doubling generally assumes that clitics are base-generated as inflections (cf. Rivas 1977; Stotzer 1976; Jaeggli 1982, 1986; Borer 1984; and more recently Sportiche 1992 who reconciles the movement vs. base-generation approach to clitic constructions but maintains that clitics do not move to their surface position but rather they are base-generated there). As already mentioned, syntactic approaches offer interesting solutions to issues such as clitic placement and clitic ordering. On the other hand, once it is recognized that clitics may co-occur with full DPs in argument position it is natural to opt for a base generation analysis of clitics in the functional domain. In the Minimalist Framework, and in particular Chomsky's (1995) Move F proposal, clitics can be naturally viewed as formal features of DPs undergoing movement to functional heads without phrasal pied piping. Anagnostopoulou (1999b) extensively argues for this view on the basis of the distribution of indirect object clitics in passive, raising and unaccusative constructions. In such an analysis, doubling clitics move to their host from argument positions and, thus, the existence of clitic doubling constructions does not challenge a movement approach to cliticization.

\section{DP-syntax ${ }^{3}$}

\subsection{Functional projections and adjective placement}

A more recent issue in the investigation of noun phrases cross-linguistically concerns the functional structure they contain. More specifically, the extension of the X-bar schema to the sentential functional elements (Chomsky 1986) and the increasing work on head-movement (Baker 1988) have led researchers to elaborate a more articulated syntactic representation for the noun phrase. Arguing that the functional nominal material should fit into the X-bar schema, Horrocks \& Stavrou (1987) (and see Szabolcsi 1983; Abney 1987; Fukui \& Speas 1986 among others), hypothesized that noun phrases, like clauses, are headed 
by a functional element. This functional head was labeled Art by Horrocks and Stavrou and D by Abney. Horrocks and Stavrou (1987) further argued that a crucial difference between English and Greek is that in English DP corresponds to IP, while in Greek DP corresponds to CP. SpecDP is not an argument position in Greek and thus wh-movement naturally takes place within this domain. The example below illustrates the interaction between $w h$-movement at the clausal level and DP-internal wh-movement (but see PhilippakiWarburton \& Papaphili 1988; and Theophonopoulou-Kontou 1988).

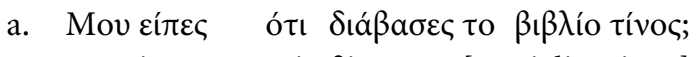 $\mathrm{mu}$ ipes oti $\delta$ javases [to vivlio tinos]
me told-2sg that read-2sG the book whose
'You told me you read whose book?'

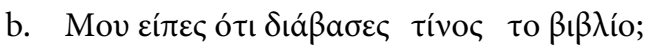
$\mathrm{mu}$ ipes oti $\delta$ javases $\left[\right.$ tinos $_{\mathrm{i}}\left[\right.$ to vivlio $t_{\mathrm{i}}$ ]
'You told me you read whose book?'

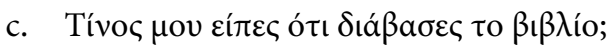 tinos $_{\mathrm{i}}$ mu ipes oti diavases to vivlio $t_{\mathrm{i}}$
'You told me you read whose book?'

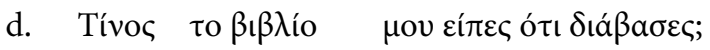 [tinos ${ }_{\mathrm{j}}\left[\right.$ to vivlio $\left.\left.t_{\mathrm{j}}\right]\right]_{\mathrm{i}}$ mu ipes oti diavases $t_{\mathrm{i}}$ 'You told me you read whose book?'

Further research on the syntax of the Greek DP has shown that no more than one functional projection between D and the lexical N is needed (see Stavrou 1999; and Karanassios 1992; Alexiadou \& Stavrou 1997 for the same conclusion based on different kind of evidence). While Picallo (1991) proposes that Catalan nouns contain in their extended projection the functional categories of Gender and Number, this does not hold for Greek. As has been shown convincingly by Ralli (1994, 1997), Gender as opposed to Number, is not a feature of the inflectional affix but it is an inherent feature of the noun stem. This in turn means that gender specification will show up under the terminal node $\mathrm{N}^{\circ}$ (see Ritter 1995) and hence no independent functional projection need be present within the nominal extended projection.

A further characteristic of Greek is that it does not show any effects of noun displacement within DP, at least with respect to the criteria that have been cross-linguistically established, i.e. affixal articles and adjective placement. Cinque (1993) and related literature have suggested that the relative order between adjectives and nouns is a criterion for assuming noun-movement in a 
language or not, under the assumption that adjectives attach to the same sites cross-linguistically. On this view, languages in which nouns precede adjectives are languages with noun movement. In Greek, all adjectives always precede the noun, as is illustrated in the examples in (33) and (34) (see Alexiadou \& Stavrou $1998 \mathrm{~b}$ for detailed discussion). Hence Greek contrasts with languages such as Italian where the head-noun precedes the adjective:

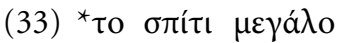

to spiti meyalo

the house big

'the big house'

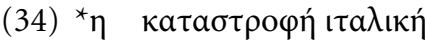

i katastrofi italiki

the destruction Italian

'the Italian destruction'

(35) a. La distruzione romana di Cartagine the destruction roman of Carthago 'the Roman destruction of Carthago'

b. ${ }^{*}$ La romana distruzione di Cartagine the roman destruction of Carthago 'the Roman destruction of Carthago'

Moreover, given that the definite article is not an affix in Greek, no argument in favor of N-to-D movement can be formulated for this language.

The distribution of the definite determiner and certain related aspects of adjectival modification in Greek DPs have received some attention within the Greek generative literature. One surprising characteristic of Greek definite DPs is that multiple occurrences of the same definite determiner in the same noun phrase are possible. This is illustrated in (36), where each adjective is accompanied by its own determiner. The phenomenon exemplified in (36) has been labelled by Androutsopoulou (1994) Determiner Spreading (DS).

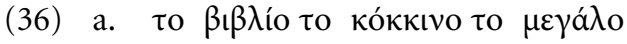
to vivlio to kokino to meyalo the book the red the big 'the big red book'

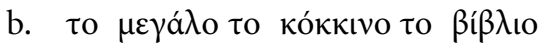

to meyalo to kokino to vivlio the big the red the book 'the big red book' 
The order of constituents in Greek noun phrases is rigid in the absence of DS. On the other hand, in the presence of DS a number of different orders become available. (37) illustrates the additional possible permutations for (36). All orderings receive one and the same interpretation:

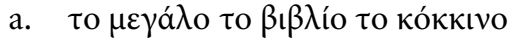 to meyalo to vivlio to kokino

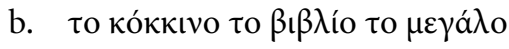 to kokino to vivlio to meyalo

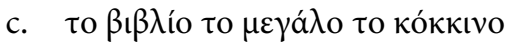 to vivlio to meyalo to kokino

Androutsopoulou adopts the proposal that pre-nominal adjectives are heads in extended N-D projection.

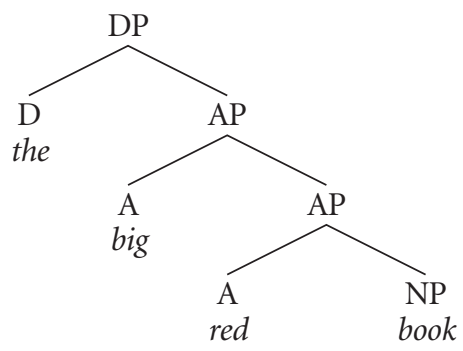

The multiple determiners that appear in DS are analyzed as instances of a new functional head within the DP projection, which she calls Def (for definiteness). Def ${ }^{\circ}$ is optionally projected above NP and AP. Def ${ }^{\circ}$ heads host formal agreement features (phi-features, Case and definiteness), which get spelled out by the relevant form of to.

On the other hand, Alexiadou \& Wilder (1998) recognize that adjectives need (or: can need) determiners of their own when they modify DPs. In their view, a closer understanding of the DS phenomenon within a theory in which multiple determiners are required anyway by the syntax of adjectival modification. Such a theory has been put forth by Kayne (1994), quite independently of the Greek facts. Thus Alexiadou \& Wilder argue that instead of being basegenerated on left branches, pre-nominal APs in DPs with DS stand in derived positions. Each AP undergoes obligatory raising to the specifier of its $\mathrm{CP}$. This is predicate raising assumed by Kayne (1994) for prenominal APs in English. Example (36b) then has the surface structure (39): ${ }^{4}$ 
(39)

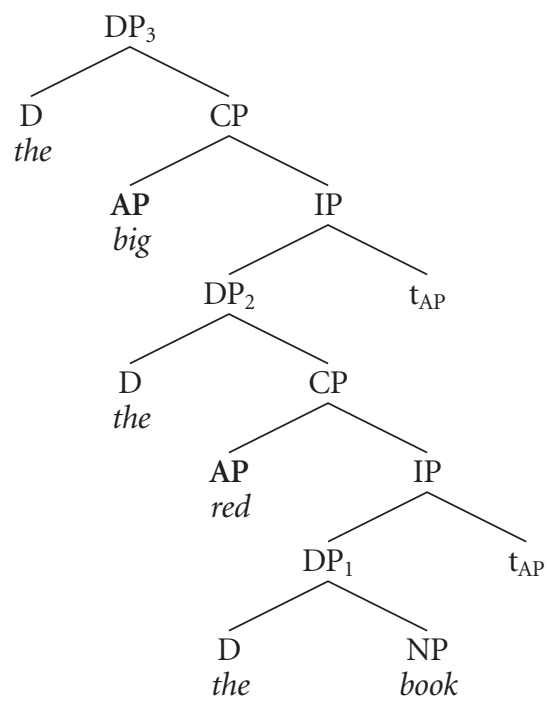

\subsection{Nominalization}

Another topic of investigation concerns nominalization. In particular, Markantonatou (1992), Kolliakou (1995), Alexiadou \& Stavrou (1998a), and Alexiadou (1999c) investigate the formation of argument taking nominals in Greek. Markantonatou's analysis is cast in terms of LFG, while Kolliakou's in terms of HPSG. Alexiadou \& Stavrou, within the Principles and Parameters approach, argue that nominals of the type in (40), so called process nominals (Grimshaw 1990) show verbal properties in that they (a) take complements and (b) can be modified by adverbs.

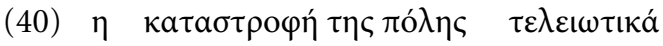

i katastrofi tis polis teliotika the destruction the city-GEN completely 'the destruction of the city completely'

In order to account for these verbal properties of nouns they assume that the nominal affix -i embeds a VP, hence the presence of adverbial modification and of an internal argument.

A different proposal is made in Alexiadou (1999c) who, following Marantz (1997) and others, proposes that there is no categorial difference between verbs and nouns. Rather nominals of the type in (40) have the properties they have as they include a set of functional projections which are standardly associated with 
verbal clauses in addition to the nominal ones they possess. Specifically, process nominals include include Voice/v and Aspect, projections linked to Events and Viewpoint Aspect. On the other hand, result nominals e.g. Sjayonisma 'exam' lack such verbal projections.

Finally, Roussou (1991) investigates a special case of nominalization in Greek, namely nominalized clauses of the type in (41):

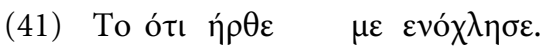

to oti ir $\theta$ e me enoxlise

the that came-3sg me bothered

'The fact that $\mathrm{s} / \mathrm{he}$ came bothered me.'

Roussou proposes that the structural analysis of (41) involves a CP which appears as the complement of the Determiner. This is possible given that $\mathrm{C}$ is nominal, as its only function is to turn a proposition into an argument. In fact, Roussou argues, the presence of $\mathrm{D}$ is necessary for reasons that have to do with case assignment. Nominalized clauses in Greek appear only in positions where other NPs receive case, i.e. in the subject or in the object position. The only way for a $\mathrm{CP}$ to receive case then is when it is preceded by the determiner.

While the presence of a determiner is licit with the complementizer 'oti', its presence with $p u$, the factive complementizer leads, according to Roussou, to ungrammaticality:

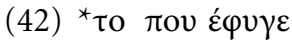

to $\mathrm{pu}$ efije

the that left-3sg

Roussou attributes this to the fact that pu is already specified [+def] and hence need not be preceded by the definite determiner.

\subsection{Clitics in DPs}

Possessive clitics in the DP have not received as much attention as clitics in the verbal domain have. In Greek possessive clitics attach either on the nominal head or appear in post-adjectival position:

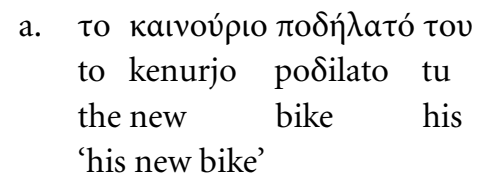




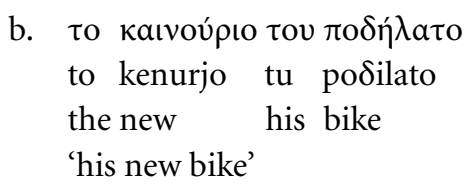

The few existing accounts of cliticization are either phonological (Nespor \& Vogel 1986) or primarily morphological (Kolliakou 1997) or morphosyntactic (Horrocks \& Stavrou 1987, 1989; Karanassios 1992). Recently, Alexiadou \& Stavrou (1999) showed that facts such as (43) above provide evidence for the existence of two possessor positions, each encoding possessorship in a different and 'special' way. The authors demonstrated that there are semantic/interpretational differences between the two cliticization sites. One such difference is illustrated below. In (44a) the possessor can be both [ \pm animate]. In (44b), where the clitic surfaces in the post-adjectival position, it can only receive an animate interpretation and hence the example is ungrammatical under the 'possessor = shop' interpretation:

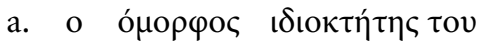
o omorfos ioioktitis-tu
the handsome owner-its
'its handsome owner'

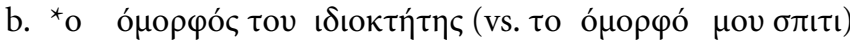

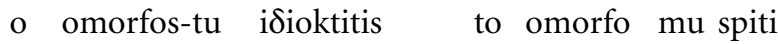
the handsome-its owner the beautiful my house
'its handsome owner/the handsome owner of the shop'

To account for this, the authors propose that the clitics are not situated in the same structural position in the above examples. In (44b) the clitic occupies a higher position in the structural representation, while in (44a) it occupies a lower one.

\section{Relative clauses ${ }^{5}$}

A first investigation of relative clauses in Greek is found in Stavrou (1984), who follows a GPSG approach, and in Joseph (1983). Standardly, relative clauses are analyzed as adjuncts to either D or NP. Alexiadou (1998), assuming an approach to relative clauses which treats them as complements of $\mathrm{D}^{\circ}$ and revives the 'Vergnaud' (1974) raising analysis, (Kayne 1994) revisits their syntax. Building on Bianchi (1995), she describes the distribution of the relative 
complementizer and the relative pronoun in Greek by comparing it to English and Italian and proposes certain modifications to the raising analysis, as these are required in order to capture the syntactic properties of Greek relative clauses. It is shown that the differences in distribution among these languages are actually related to some properties of the functional structure of the sentence, especially the Comp 'area', which in recent years has been argued to consist of a number of functional projections.

An asymmetry in the distribution of clitics in Greek (restrictive) relative clauses has been discussed in Stavrou (1984) and Alexiadou \& Anagnostopoulou (2000). Stavrou notes that the presence of a clitic is obligatory in appositive relatives, but is unacceptable in the restrictives. This is indicated in (45) below:

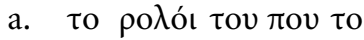
aүópaoe
$\sigma \tau \eta \nu$

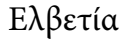
to roloi tu pu to
ayorase stin elvetia
the watch his that CL-ACC bought-3sg in the- Switzerland 'his watch that he bought in Switzerland'

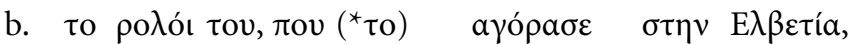 to roloi tu pu to ayorase stin elvetia the watch his that CL-ACC bought-3sg in.the Switzerland 'his watch that he bought in Switzerland'

Stavrou (1984) distinguishes between types of clitics that are present in appositive relative clauses and clitics which are present in restrictive relatives. With respect to the former she proposes that the presence of a clitic can be explained by the notion of topicalization. Crucially, for Stavrou the clitic topicalizes the head of the relative clause. Thus, the presence of a clitic is dependent on whether the head of the relative can be seen as a topic or not and the clitic is not involved in the process of relativization.

However, as also noted by Stavrou, clitics can be licensed when the 'head' of the relative clause is a QP or an indefinite, while they cannot be licensed when the 'head' of the relative is a definite. This point is investigated further in Alexiadou \& Anagnostopoulou (2000) and Tsimpli (1999).

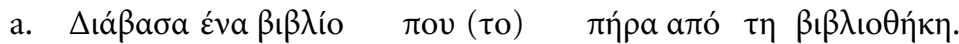

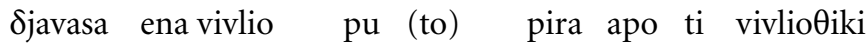
read-1SG a book-ACC that CL-ACC got from the library-ACC 'I read a book that I got from the library.'
} 


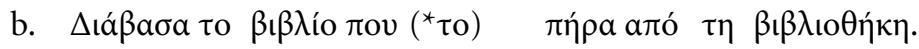

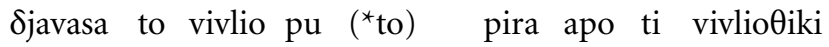 read-1s the book that CL-ACC got from the library-ACC 'I read the book that I got from the library.'}

Alexiadou \& Anagnostopoulou argue that the clitic can be analysed as forming a constituent with the raised NP. In other words, the clitic 'doubles' the raised NP. As they show, the clitic construction is sensitive to strong islands, a fact which supports a movement analysis from a clitic doubling input. In this view, the restrictions on the distribution of clitics reduce to restrictions on clitic doubling. There are a number of constraints on the morphological and semantic nature of doubled NPs across languages. ${ }^{6}$ One such constraint is that DO doubling clitics can never be associated with bare NPs. The Greek sentence in (47) illustrates this:

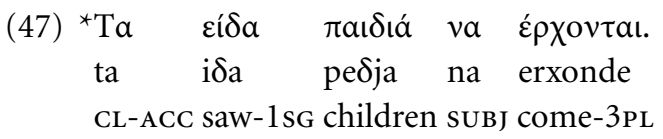

Given this analysis, a RRC headed by a definite determiner results from an input of the type illustrated in (46), i.e. it involves a bare phrase doubled by an accusative clitic. Since this is an impossible structure to begin with, the resulting relative is also impossible. Hence, the distribution of clitics in Greek constitutes a language-specific argument in favor of a head raising analysis for relative clauses.

A different approach is taken in Tsimpli (1999). Tsimpli provides an interesting theoretical and empirical link between clitic- containing and operator-variable structures, examining clauses involving null and overt operators in English and in Greek, alongside the distribution of clitics in Deleted Object Constructions (of the 'tough'- type), purposive clauses, matrix interrogatives, restrictive and appositive relative clauses. All of these involve the presence of an operator, realized or null. Tsimpli shows that an object clitic is obligatory whenever an operator can bind the clitic (or the empty subject, in the constructions where there is one), as when it is non-quantificational; coreferentiality in these cases between the clitic and its antecedent in an argument position in the matrix clause is further due to the predicational relationship between the antecedent and the CP clause. In the related English sentences there is a null epithet with a fixed reference rather than an overt pronoun, because feature identifiers are not available. The clitic is excluded, however, when the relevant operator is quantificational (thus lacking a referential index), since the clitic is 
a specificity marker. In relative clauses with indefinite heads, a clitic is optionally present, and this is due to the fact that the indefinite head of the RC in these cases gets a specific reading (Enç 1991); given further the predicational relationship between the RC and the head of which this is predicated, it is assumed that the clitic enters a predication relationship with the indefinite NP head. This relationship is mediated through the (null) operator in the $\mathrm{CP}$ which $\overline{\mathrm{A}}$-binds the clitic. In the case of appositive relatives, the operator is assumed to be nonquantificational, so that it does not contribute to the recoverability of the reference and Case feature; thus, the clitic acquires a referential index with the head NP in A-position via $\bar{A}$-binding plus predication indexing. Similarly, in embedded interrogatives the clitic can be present because there is a nonquantificational operator in the local $\mathrm{CP}$ which can $\overline{\mathrm{A}}$-bind the clitic.

\section{Subjects in subjunctive clauses}

Greek has no infinitives. All its moods (indicative, subjunctive, imperative) are expressed by finite forms throughout; specifically, the 'subjunctive' mood consists of the particle na plus fully inflected forms of the verb, being the common translational equivalent of the English infinitive:

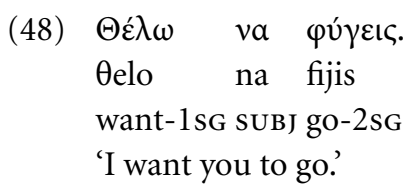

This characteristic is shared to some degree by the languages of the Balkan Peninsula, Greek, Albanian, Macedonian, Bulgarian, Serbo-Croatian, and Romanian which are said to form a Sprachbund (see Joseph 1983 for discussion).

An issue of controversy among linguists is whether or not $n a$ - clauses involve Control. That $n a$-clauses do not always involve Control can be illustrated with cases where the embedded subject need not be interpreted as coreferential with the matrix subject and where lexical NPs can be licensed in the embedded subject position.

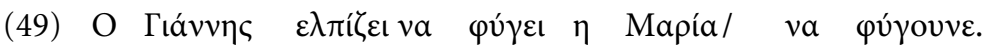
o janis elpizi na fiji i maria/ na fiүune the John-Nom hopes subj go-3sg the Mary-Nom subj go-3PL 'John hopes that Mary goes/John hopes that they go.' 
According to one view (Philippaki-Warburton 1987; Philippaki-Warburton \& Catsimali 1999), na clauses never display Control because the empty category PRO cannot occur in a finite clause understood as a clause in which the verb inflects for person. Another view holds (Iatridou 1993; Terzi 1992; Varlokosta 1994 and others) that despite the lack of infinitives, the subject of the embedded clause must still be PRO in some cases. Since both sides present interesting arguments, we choose to focus here on the arguments rather than the analyses.

Iatridou (1993) gives a number of reasons for the existence of Control. She points out that in many cases, the embedded verb, similarly to the matrix verb, shows agreement in number and person with the matrix subject obligatorily. When the lower verb does not agree in person (51a) and number (51b) with the matrix subject ungrammaticality arises:

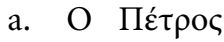

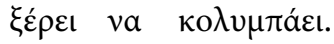
o petros
kseri na kolimbai
the Peter-nom.sg knows subj swim-3sg
'Peter knows how to swim.'

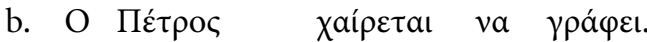
o petros xerete na $\gamma$ rafi

the Peter-NOM.sg is.glad-3sg subj write-3sg

'Peter is happy to write.'

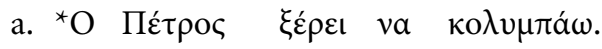
o petros kseri na kolimbao
the Peter-Nom knows subj swim-1sG
o petros kseri na kolimbane
the Peter-Nom knows sUbj swim-3PL

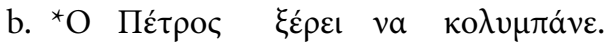

She further notes that exactly in those contexts where agreement between the lower verb and the higher subject is obligatory, overt subjects in the embedded clause are ungrammatical and, moreover, that the reference of the embedded subject is obligatorily determined by the higher subject (53a) or object (53b), depending on the matrix predicate:

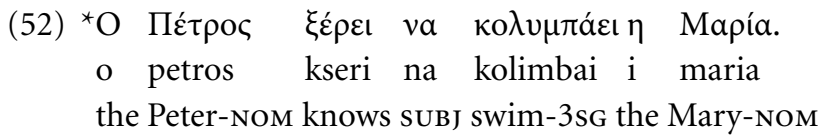




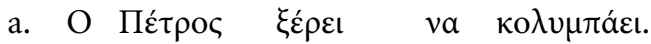
o petros kseri na kolimbai
the Peter-nom know-3sg subj swim-3sg
'Peter knows how to swim.'

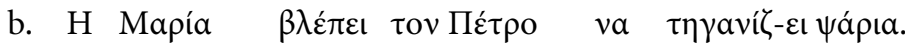
i maria vlepi ton petro na tipaniz-i psaria
the Mary-nom see-3sg the Peter-ACC subj fry-3sg fish
'Mary sees Peter frying fish.'

Iatridou (1993) concludes that the fact that (i) overt subjects are impossible and (ii) the reference of the understood subject is obligatorily linked to the arguments of the matrix verb is evidence for Control because only in structures with PRO and not in structures with pro do such facts obtain.

Concerning the factor licensing PRO in Greek subjunctives, Iatridou (1993) points out that in cases showing properties of Control the embedded clause lacks Tense, in the sense that it does not show [ \pm Past $]$ specifications:

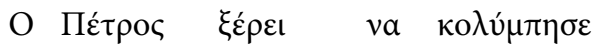

$$
\begin{aligned}
& { }^{*} \text { o petros kseri na kolimbise } \\
& \text { the Peter-Nom know-3sg subj swim-PAst.3sg }
\end{aligned}
$$

On the basis of this, Iatridou (1993) proposes that in Greek, lack of Tense results in lack of nominative Case and that [-Tense] assigns Null Case to PRO. This proposal is further supported by the observation that with certain predicates like fandazome ('imagine'), when object control takes place the $[ \pm$ Past $]$ distinction in the lower clause is impossible, while when the embedded subject surfaces with nominative Case, the lower clause can show $[ \pm$ Past $]$ distinctions:

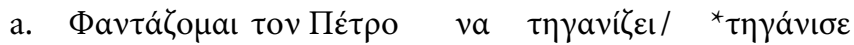
fandazome ton petro na tiүanizi/ ${ }^{\star}$ ti imagine-1sg the Peter-ACC SUbJ fry-3sG.PREs ${ }^{\star}$ fry-3sG.PAST

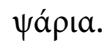
psaria fish 'I imagine Peter frying/*fried fish'
} 


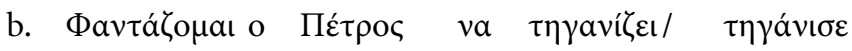
fandazome o petros na tijanizi/ tijanise imagine-1sG the Peter-NOM SUBJ fry-3sg.PREs / fry-3sg.PAST

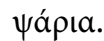
psaria fish 'I imagine Peter frying/fried fish'

An additional argument comparative in nature can be found in Terzi (1992). Terzi (1992) points out that Greek subjunctives, unlike Romance subjunctives, do not show subject-obviation. While embedded and matrix subjects must be obligatorily disjoint in reference in Romance subjunctives (56), this is not the case in Greek (57):

(56) $\operatorname{Juan}_{\mathrm{i}}$ quiere que $\mathrm{EC}_{\mathrm{j} / \star_{\mathrm{i}}}$ venga Spanish John wants that comes-suBj 'John $n_{\mathrm{i}}$ wants that he $\mathrm{j}_{\mathrm{j} / \star_{\mathrm{i}}}$ comes.'

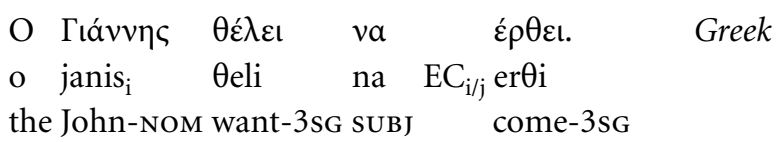
'John ${ }_{\mathrm{i}}$ wants that he $\mathrm{i}_{\mathrm{i} / \mathrm{j}}$ comes.'

Terzi argues that Greek subjunctives behave like infinitives and not like Romance subjunctive clauses, and that the similarity between Greek subjunctives and infinitives can be straightforwardly captured in terms of an analysis involving control.

Terzi differs from Iatridou in that she does not consider the [ \pm Tense] property as being responsible for Control, as there are contexts in which the [ \pm Past] opposition is impossible and yet nominative Case is possible:

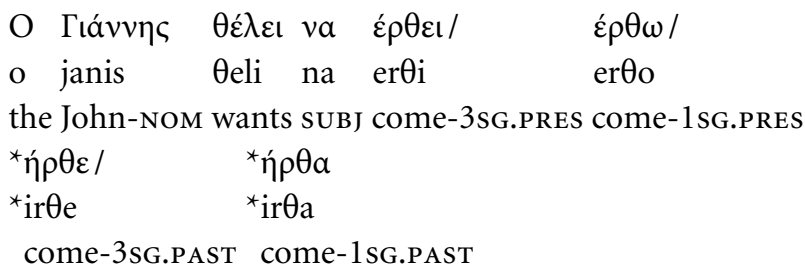

Instead she proposes that $n a$ assigns Null Case to PRO in its Specifier position while subjunctive complements with a pro or lexical subject involve Verb Movement to the embedded $\mathrm{C}$ resulting in a VS order. 
A final set of arguments based on the properties of the null subject with respect to binding can be found in Varlokosta (1994). Varlokosta (1994) notes that the subject of certain subjunctive complements in Greek displays a number of properties characterizing anaphoric rather than pronominal elements, namely, it forbids split antecedents (59a), permits only sloppy readings under ellipsis (59b) and requires a de se interpretation (59c):

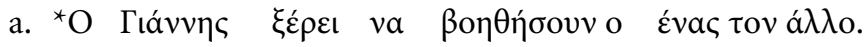
o janis kseri na voiӨisun o enas ton alo the John-Nom knows subJ help-3PL the each the other

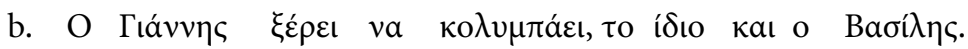

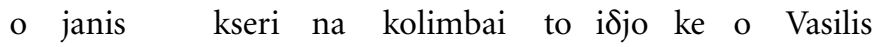
the John-NOM knows subJ swim-3sg the same and the Bill 'John knows how to swim and so does Bill.'

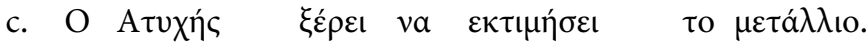
o atixis kseri na ektimisi to metalio
the Unfortunate knows sUBJ appreciate-3sg the medal-ACC
'The Unfortunate knows how to appreciate the medal.'

Varlokosta argues that the above properties can be explained if the subject of the embedded clause is PRO and not if it is pro because PRO is a pronominal anaphor $[+\mathrm{p},+\mathrm{a}]$ while pro is $[+\mathrm{p},-\mathrm{a}]$, i.e. it does not have anaphoric properties (Chomsky 1981).

Concerning the licensing Conditions for PRO, Varlokosta (1994) refines Iatridou's correlation between Tense and Case and introduces a distinction between morphological and independent/semantic Tense. Varlokosta argues that while obligatory and Optional Control take place in clauses which lack morphological Tense, obligatory Control is further conditioned by the absence of independent temporal reference in the embedded clause (Stowell 1983). Thus complements of optional Control verbs such as $\theta$ elo 'want' lack morphological Tense, but they show evidence for the presence of independent Tense, as is evident from the fact that they can be modified by adverbs with temporal reference different from the reference of the matrix predicate:

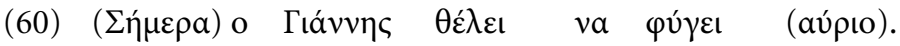 (simera) o janis $\theta$ eli na fiji (avrio)
today the John-Nom want-3sg subj leave-3sg tomorrow 'John wants (today) to leave tomorrow.'

Such complements also show evidence for the presence of Case as they may license NP subjects with nominative Case: 

(61)

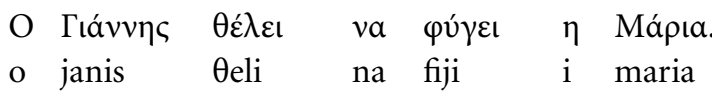
the John-Nom want-3sg subj leave-3sg the Mary-Nom 'John wants Mary to leave.'

On the other hand, complements of obligatory Control verbs such as ksero 'know how' lack morphological Tense, and they also lack independent Tense:

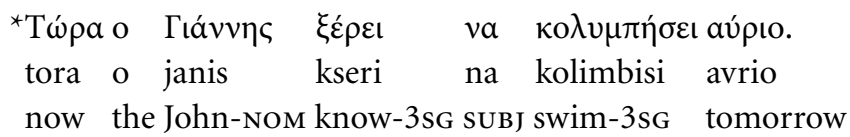

The fact that an embedded subject cannot be licensed in such cases (63) further shows that the absence of nominative Case depends on the absence of independent Tense:
(63) $\times($

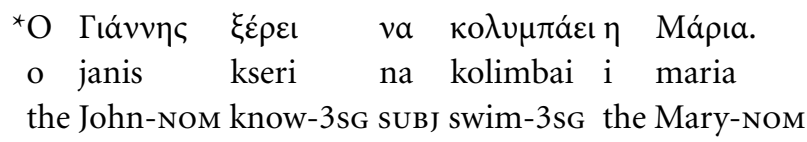

The Tense properties of subjunctive complements are examined also in Roussou (1999) from a different perspective. The basic claim there is that embedded subjunctives in Greek are licensed by matrix sentential operators such as negative, Q, conditional, necessity and possibility, and that they therefore have much in common with indefinite expressions (i.e. by functioning as a kind of polarity item). This is expressed by means of a local head dependency between the relevant matrix and the embedded (subjunctive) T. An important distinction is drawn, however between epistemic ('think' etc.) and volitional predicates in that the former are not normally inherently modal and so may take subjunctive complements only in the context of an appropriate matrix modality (neg, Q, etc.). Furthermore, they alone permit independent time reference in their complements, thus permitting the appearance of past tense forms in combination with the subjunctive-marking particle na. This difference is explained as follows. Like true epistemic modals expressing possibility and necessity, epistemic predicates like 'think' necessarily display a 'pleonastic' present tense (the verb form regularly used for temporally 'neutral' situations, reflecting here the fact that the expression of epistemic modality is timeindependent). This means that the normal time-anchoring of an embedded verb to the time reference of the matrix fails; instead, the T-dependency is headed here by an expletive $\mathrm{T}$ in the matrix, and the temporal evaluation of the chain that it heads must then be derived from the time reference of the embedded $\mathrm{T}$. 
The temporal independence of the subjunctive complements of epistemic verbs is thus a natural consequence of the analysis.

Having presented a number of different arguments in the literature for a Control structure, let us now turn to the arguments against it.

Philippaki \& Catsimali (1999) argue that a major problem for Control is posed by the fact that there is evidence that the missing subject is not uncased but rather it has nominative case. This evidence comes from a number of observations. First of all, predicate adjectives in the embedded clause have morphologically distinct nominative case, a fact which can be explained if the subject of the embedded clause is pro with nominative Case:

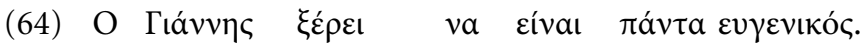 o janis kseri na ine panda evjenikos the John-NOM know-3sg sUвJ be-3sg always polite-NOM.sG 'John knows how to be always polite.'

The nominative Case on the predicate in the embedded clause cannot be argued to derive from a long-distance agreement process with the overt DP in the main clause because in constructions that have been analysed as object control in Iatridou (1993) the controller has accusative Case while the predicate has nominative:

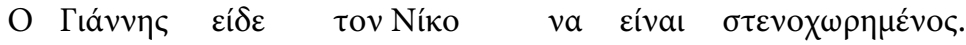

$$
\begin{aligned}
& \text { o janis ide ton niko na ine stenoxorimenos } \\
& \text { the John-Nom saw-3sg the Nikos-ACC subj be-3sg sad-Nom.sG } \\
& \text { 'John saw Nikos being sad.' }
\end{aligned}
$$

Furthermore, NP-modifiers and intensifiers in the embedded clause are specified for nominative case morphology:

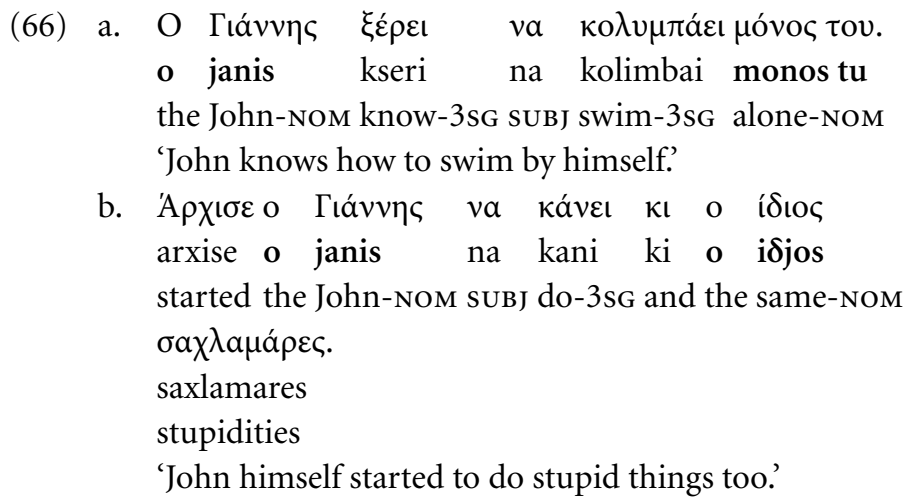


Another piece of evidence against the control analysis comes from the observation that in environments that are agreed upon by the proponents of the control analysis to display obligatory control, overt subjects are under certain conditions possible. This is the case, for instance, in coordination structures of the type illustrated in (67) as well as cases like (68) where it is difficult to argue that the subject NP, which appears in a position to the right of the embedded verb, is dislocated to the right of the matrix clause because the PP that follows belongs to the embedded clause:

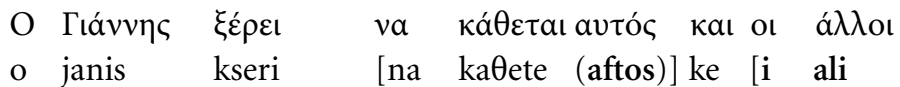
the John-Nom knows-3sg sUBJ sit-3sg he and the others-Nom

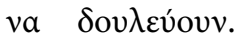
na $\delta$ ulevun] SUBJ work-3PL

'John knows how to sit while others do the work.'

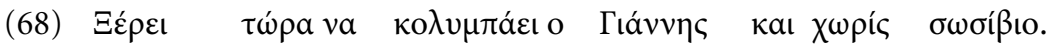
kseri tora na kolimbai o janis ke xoris sosivio know-3sg now suBj swim-3sg the John-NOM and without life-jacket 'John knows now how to swim even without a life-jacket.'

The final argument comes from the observation that Greek lacks PROarb constructions, which are always possible in languages that have Control.

On the basis of this evidence, Philippaki-Warburton \& Catsimali (1999) conclude that the empty category in Greek subjunctives is always pro, and that in cases when obligatory coreference is found, this is satisfied at a semantic and not a syntactic level.

Before concluding the discussion in this section, we would like to point out that Anagnostopoulou (1999b) and Alexiadou \& Anagnostopoulou (1999a) have recently argued that Greek has (feature)-Raising out of subjunctive complements of the aspectual verbs arxizo 'start' and stamatao 'stop' (which have been analysed in terms of either PRO or pro) because the subject is obligatorily interpreted in the lower clause and yet it agrees with both the matrix and the embedded verb obligatorily. This can be shown, for example, on the basis of the distribution of nominative anaphors bound by object experiencers in (69) (more evidence comes from subject idioms and WCO effects, see Anagnostopoulou 1999b and Alexiadou \& Anagnostopoulou 1999a for details): 


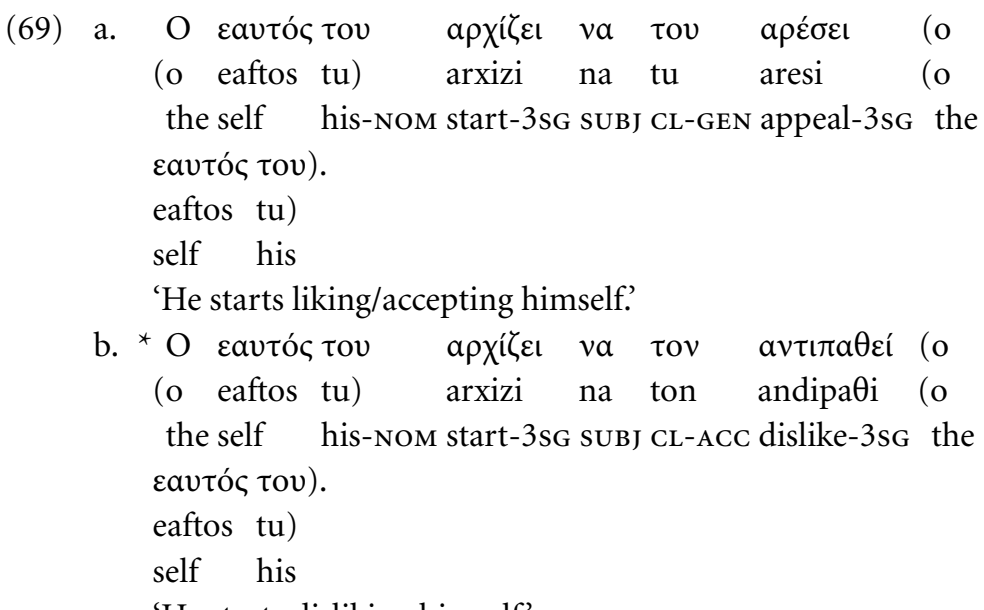

If the Raising analysis is correct, and if Raising depends on absence of Case in the embedded clause as is standardly assumed, then this provides evidence for a dissociation of abstract Case as a syntactic feature and agreement as a surface morphological effect (Marantz 1991; Schütze 1997). Thus, the overall picture is more complicated than assumed so far.

\section{Anaphors}

The Greek anaphor 'o eaftos tu' (the self his) has the form and the structural properties of a definite description, consisting of the definite determiner $o$, the head noun eaftos and the possessive clitic $t u$, which varies in $\varphi$-features according to its antecedent:

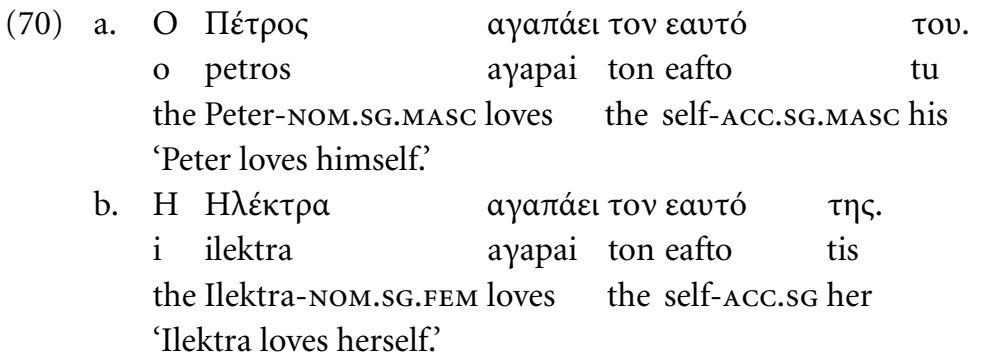

Based on evidence from clitic doubling, Iatridou (1988) argues that the Greek anaphor is not subject to Principle A as we know it from Government and 
Binding Theory. According to Iatridou, this is due to the fact that only the possessive clitic is coindexed with its antecedent and not the anaphor as a whole, a property she attributes to the DP structure of $o$ eaftos $t u$. Building on Iatridou's analysis, Anagnostopoulou \& Everaert $(1996,1999)$ and Everaert \& Anagnostopoulou (1997) analyse the Greek anaphor within Reinhart \& Reuland's (1993) "Reflexivity" theory of anaphora. They argue that because of its structural properties and its feature specification, $o$ eaftos tu qualifies as a $[+\mathrm{R},+\mathrm{SELF}]$ anaphor. Being $[+R]$ (i.e. fully specified for $\varphi$-features), the Greek anaphor is not allowed to form an A Chain with its antecedent because R\&R's Chain Condition does not permit formation of an A Chain consisting of two [+R] links. For this reason, the Greek anaphor is not subject to the usual configurational effects showing up with $[-\mathrm{R},+\mathrm{SELF}]$ anaphors like English himself, for example nominative anaphors are permitted in certain contexts (experiencerobject constructions, cf. Anagnostopoulou 1999a), unlike English himself.

Another interesting anaphoric element in Greek is the element $o$ idios ('the same'). As has been observed by Iatridou (1986), this element behaves like an anaphor in requiring a sentence internal antecedent, but unlike an anaphor in requiring its antecedent to be outside of its Governing Category:
a. ${ }^{\star} \mathrm{H}$ Mapía

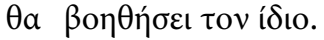
i maria
$\theta$ a voïisi

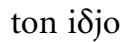
the Mary-NOM.FEM will help the same-ACC.MASC

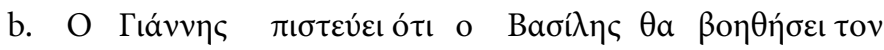
o janis $_{i}$ pistevi oti o vasilis $s_{j} \theta$ voitisi ton
the John-Nom believes that the Bill-Nom will help the ísto.
$\mathrm{i} \delta \mathrm{jo}_{\mathrm{i} / * \mathrm{j} / * \mathrm{k}}$
same-ACC.MASC
'John believes that Bill will help him'

Varlokosta \& Hornstein (1993) and Varlokosta (1994) argue that the domain in which ton iojo must be free is not exactly its governing category, but rather the first CP containing it. In the spirit of Enç (1989) and Koopman \& Sportiche

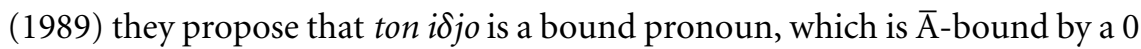
operator in SpecCP. 


\section{Factive complements}

Greek has two distinct complementizers: ot $i$ and $p u$. The former introduces mainly complements of epistemic verbs, the latter introduces complements of factive, psychological and perception predicates (Christidis 1981; Roussou 1992, 1993; Varlokosta 1994; Ginzburg \& Kolliakou 1997):

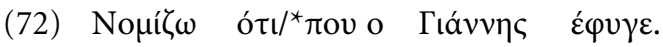
nomizo oti $/{ }^{*} \mathrm{pu}$ o janis efije

think-1sG that/that the John-Nom left

'I think that John left.'

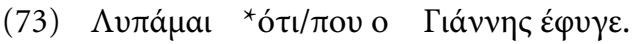
lipame ${ }^{*}$ oti/pu o janis efije regret-1sG that/that the John left 'I regret that John left.'

It has been assumed that pu-complements encode factivity, in the sense that they overtly express the semantic property [+factive], which in English is not encoded morphologically through the presence of a special category (Christidis 1981, 1986; Roussou 1992, 1993; and partially also Varlokosta 1994; see Ginzburg \& Kolliakou 1997 who argue for an analysis in terms of lexically specified restrictions on the verb). Assuming that they are factive, the interesting property of $p u$-complements is that they constitute islands not only for adjunct extraction but also for argument extraction:

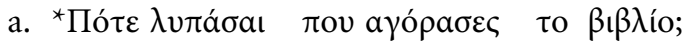 pote lipase $\mathrm{pu}$ ayorases to vivlio $t$ when regret-2sG that bought-2sG the book

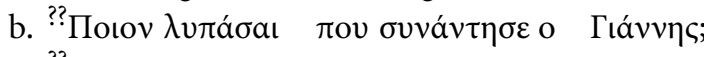 ?? pjon lipase pu sinandise o janis $t$ whom regret-2sg that met-3sg the John-NOM 'Who do you regret that John met?'

In this respect, they differ from their counterparts in English, which only block adjunct extraction and they do not interfere with argument extraction, as indicated in the translations of the Greek examples in (74) (Cinque 1990; Hegarty 1992; Kiparsky \& Kiparsky 1971).

To account for these facts, Roussou $(1992,1993)$ argues that (i) the complementizer $p u$ is a factive complementizer that possesses the feature [+definite] (cf. Roussou's treatment of lack of nominalizations with pu-complements 
mentioned above) and (ii) factive complements have an empty operator in SpecCP which binds the event position of the verb. The difference between English and Greek follows from the assumption that in Greek the complementizer agrees with the factive operator because it is specified as [+definite], while in English no such agreement obtains.

On the other hand, Varlokosta argues on the basis of the distribution of the bound pronoun $o$ idios in factive complements that there is no operator in SpecCP in $p u$-complements. She further argues that $p u$ does not always denote factivity but it can also denote direct perception and that syntactically, there is a distinction between the $p u$-complements of psych verbs and the $p u$-complements of factive verbs with respect to the status of extractions. Varlokosta proposes an analysis in terms of parataxis which builds on an idea discussed in Davidson (1969) and is extended in Torrego \& Uriagereka (1993) on the nature of indicative embedded clauses.

\section{Argument structure}

\subsection{Unaccusatives}

The structure of intransitive predicates in Greek and their status with respect to the unaccusativity hypothesis has been the focus of a number of studies (Markantonatou 1992; Kakouriotis 1993; Alexiadou \& Anagnostopoulou 1998b, 1999b; Sioupi 1997; Embick 1998; Theophonopoulou-Kontou 1999 among others).

Markantonatou (1992), and Alexiadou \& Anagnostopoulou (1998b) are concerned with the establishment of criteria which distinguish intransitive verbs into unergatives and unaccusatives in Greek, a language where most of the standard tests used to distinguish between the two verb classes fail to apply. All intransitive verbs select auxiliary exo 'have'. Greek also lacks ne-cliticization, resultatives (cf. 75), and impersonal passives (cf. 76):

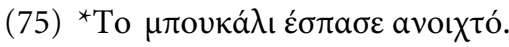

to bukali espase anixto

the bottle broke open

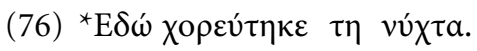
eঠo xoreftike ti nixta here was.danced the night 
Markantonatou (1992) has pointed out two diagnostics that can be used in Greek to distinguish unaccusative from unergative predicates. For instance, a test that can be used is the availability of adjectival participles with the former but not with the latter (cf. 77a vs. 77b):

(77) a. pesmeno filo

fallen leaf

b. ${ }^{*}$ tre menos an $\theta$ ropos

run man

Alexiadou \& Anagnostopoulou (1997b) add certain criteria to the ones proposed in Markantonatou and address the question whether all criteria diagnose the same properties or not. The authors, following the proposal in Levin \& Rappaport (1995), conclude that one needs to distinguish between criteria of 'deep' unaccusativity and criteria of surface unaccusativity, which cannot be considered real unaccusativity diagnostics.

Another topic that figures prominently in the discussion on unaccusativity relates to the morphological marking on the intransitive predicate. In many languages, Greek being one of them, intransitive verbs participating in the causative alternation show morphology associated with intransitivization. This morphology is sometimes but not always present, as is shown in (78) and (79):

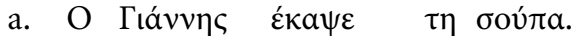
o janis ekapse ti supa
the John-Nom burnt-ACT the soup-ACC
'John burned the soup.'

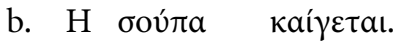
i supa kejete
the soup-NOM burns-NONACT
'The soup is burning.'

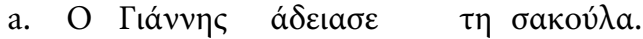
o janis adjase ti sakula
the John-Nom emptied-ACT the bag-ACC
'John emptied the bag.'

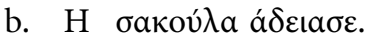
i sakula abjase
the bag-NOM emptied-ACT
'The bag emptied.'

Apart from inchoatives, there are four other syntactic environments in which Non-active morphology appears in Greek. These are illustrated in (80). The first 
three examples in (80) are cases in which Non-active morphology occurs in an alternation. The fourth case involving the Non-active form, namely deponent verbs (Mackridge 1985; Embick 1998), is not part of an alternation. Deponents are transitive verbs which lack active forms altogether. Syntactically, deponent verbs behave exactly like all other transitive verbs. This is illustrated in (80d), where the deponent verb takes a nominative subject and an accusative object. Coming to the syntactic alternations, passive verbs constitute the first environment (80a). Passive verbs always show the Non-active (see also Smirniotopoulos 1992). Furthermore, Non-active morphology appears with two distinct types of reflexives. The first of these, illustrated in (80b), shows a verb without a direct object in the Non-active with an inherent reflexive interpretation. The second type, illustrated in (80c), shows a transitive verb 'destroy' prefixed with the element afto 'self'. In this case, it is the combination of the element afto and the Non-active morphology which is associated with the reflexive interpretation; without afto the result is simply a passive. This type is arguably derived by self-incorporation (cf. Rivero 1992; Smirniotopoulos \& Joseph 1998).
a. To $\beta ı \beta \lambda i ́ o$

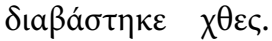
Passives
to vivlio

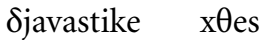
the book-NOM read-NONACT yesterday
'The book was read yesterday.'

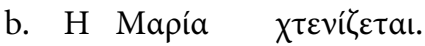
i maria xtenizete
the Mary-NOM combs-NONACT
'Mary combs herself.'
Reflexives

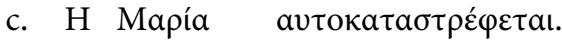
i maria aftokatastrefete
the Mary-NOM self-destroys-NONACT
'Mary destroys herself.'

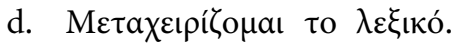
Deponents
metaxirizome to leksiko
use-NONACT.1sG the dictionary-ACC
'I use the dictionary.'

Such marking appears also on certain middle predicates (see the extensive discussion in Condoravdi 1989):

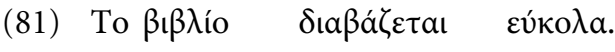
to vivlio Sjavazete efkola
the book-NOM reads-NONACT easily
'The book is easily read.' 
With respect to the presence of the non-active morphology in the above constructions, Tsimpli (1989) has argued that in passives the non-active affix is generated under Infl and is assigned the external theta-role of the verb. A similar derivation is proposed for the middle construction in (81). The difference between passives and middles in Tsimpli's account is that the aspectual modification on the affix differs. In the case of middles the affix is marked [+imp] hence the generic interpretation middles receive. On the other hand, reflexives of the type in (80b) involve attachment of the affix in the lexicon.

Condoravdi (1989), and Sioupi (1997) discuss the Greek middle construction in some detail. While Condoravdi proposes that Greek verbs split into two groups, one that forms middles with active morphology, and one that makes use of the non-active pattern, Sioupi argues that the middle construction in Greek surfaces only with non-active morphology. For Sioupi strings involving active morphology are best analyzed as unaccusative predicates (see also Kakouriotis 1993 for a comparison of middles in Greek and English).

According to Embick (1998), voice morphology does not correspond to any syntactically active element. Non-active is a morphological feature which is assigned in specific syntactic configurations, and reflects properties of the syntactic environment rather than itself effecting an alternation. The feature [nonact] is assigned postsyntactically to the verb when it (or the $\mathrm{v}-\mathrm{V}$ complex) is not in a local relationship with an external argument. On this view, voice features are properties of Morphology, and thus all occurrences of [nonact] belong to the Morphology component. The difference between deponent verbs and passives, reflexives and inchoatives, is that the former are specified for this feature inherently, while the latter are assigned this feature in a particular syntactic configuration. Embick's proposal for the syntactic alternations is illustrated in (82):

$$
\mathrm{V} \rightarrow \mathrm{V}-\mathrm{VOC}[\text { NonAct }] / \ldots \text { No external DP argument }
$$

As the data in (79) show, in certain cases, the intransitive member of the causative-inchoative alternation bears no such morphology, while passives always display this morphology, as stressed especially by TheophanopoulouKontou 1999. To account for this, Alexiadou \& Anagnostopoulou (1999b) propose that predicates such as (79) above are basic intransitives, while predicates such as the ones in (78) are transitives which become intransitive (see also Embick 1998).

There are also cases where active morphology appears on the transitive and the intransitive when the argument is [-animate], while Non-active morphology appears on the intransitive when the argument is [animate]: 


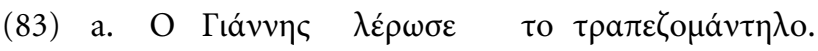

o janis lerose to trapezomandilo

the John-NOM dirtied-ACT the tablecloth-ACC

'John dirtied the tablecloth.'

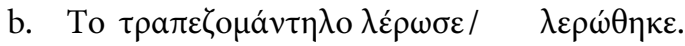

to trapezomandilo lerose/ lero $\theta$ ike

the tablecloth-NOM dirtied-ACT /-NONACT

'The tablecloth got dirty.'

While for Theophanopoulou-Kontou (1999) this fact suggests a double classification of the respective verbs, Alexiadou \& Anagnostopoulou argue that Non-active morphology is sensitive to the presence of the feature [+animate/ +volitional]. This correlates with the fact that verbs that are standardly classified as inherent reflexive verbs in Greek, necessarily have Non-active morphology and take animate arguments.

\subsection{Experiencer predicates and ditransitive predicates}

Different aspects of the syntax of experiencer predicates have been discussed in Kakouriotis (1993), and Anagnostopoulou (1999a). Kakouriotis (1993) is specifically interested in alternations of the type in (84) which he analyses as special instances of the causative-inchoative alternation (see Levin \& Rapapport 1995 for discussion and references):

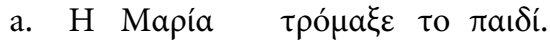
i maria tromakse to pe $\delta \mathrm{i}$
the Mary-nom scared the child-ACC
'Mary scared the child.'

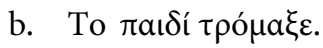
to pedi tromakse
the child got-scared
'The child got scared.'

On the other hand, Anagnostopoulou (1999a) considers the properties of experiencer-object predicates (Belletti \& Rizzi 1988; Grimshaw 1990; Pesetsky 1995) and argues for an analysis along the lines of Grimshaw (1990) according to which both aspectual and thematic factors govern the syntactic mapping of arguments.

The lexical and syntactic properties of ditransitive predicates have been discussed in Catsimali (1990), Markantonatou (1994), Dimitriadis (1999) and 
Anagnostopoulou (1999b). Catsimali is specifically interested in constructions in which both arguments surface as DPs with morphological genitive and accusative case:

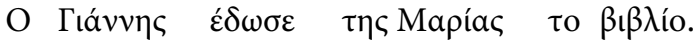

$$
\begin{aligned}
& \text { o janis edose tis marias to vivlio } \\
& \text { the John-Nom gave-3sg the Mary-GEN the book-ACC } \\
& \text { 'John gave Mary the book.' }
\end{aligned}
$$

She compares this construction to the double object construction in English and argues that the Genitive construction does not show the asymmetries the English double object construction shows with respect to (i) binding (Barss \& Lasnik 1986) and (ii) Case (Larson 1988). She argues that the Greek facts can be best accommodated under a non-configurational approach. Anagnostopoulou (1999b) reaches the opposite conclusion, namely that the Greek Genitive construction in (85) structurally corresponds exactly to the English double object construction, up to the difference in the morphological case of the indirect object. ${ }^{7}$ Markantonatou (1994) investigates the lexical properties of the genitive construction in Greek and argues that many of the conditions characterizing the double object construction in English are found in the Greek genitive construction as well. However, there are also some differences. Finally, Dimitriadis (1999) investigates the dative alternation in Northern Greek and the syntactic role of indirect object clitics in Northern and Southern Greek dialects.

\section{The structure of PPs}

The structure of prepositional phrases, their type and their case assigning properties have been examined in Theophanopoulou-Kontou (1997) and Fykias (1997). Theophanopouloup-Kontou discusses at length the alternation between ADV + PP vs. ADV + GEN.clitic illustrated below:

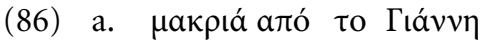

makria apo to jani

away from the John-ACC

'away from John'

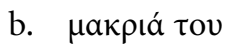

makria tu

away him

'away from him' 
Theophanopoulou-Kontou, building on Cardinaletti \& Starke (1995), argues that clitics are impoverished DPs. She then proposes that PPs and clitic gen. are structurally related, both representing DPs and expressing a locative. Such constructions constitute evidence for the existence of a deeper abstract case system, a view also defended in Fykias (1997). P is not analysed as merely a case marker, but it bears inherent meaning.

\section{Conclusion}

In this article we concentrated on topics that have attracted a lot of attention in the more recent literature in the study of Greek Syntax. We believe that this overview reflects the fact that the study of Greek has become important for the development of generative theory, as many of the issues discussed here are currently highly relevant for the development of a satisfactory theory of comparative syntax.

\section{Notes}

* We would like to thank the editors of the Journal of Greek Linguistics for their comments. Thanks to David Embick for comments and for checking our English.

1. It has been pointed out to us that the judgements on the sentences in (17) are not shared by all native speakers. Moreover, Philippaki-Warburton (forthcoming) develops an alternative account to the one outlined in Alexiadou (1999a).

2. One could imagine ways in which the two could become compatible, for example by proposing that the step in which multiple checking takes place is not spelled out at PF, which is where the LCA applies.

3. In our discussion on the DP we leave out the syntax of Possessors. The syntax of Possessors is discussed in Mouma (1993), Alexiadou \& Stavrou (1997), Alexiadou (1999c) among others.

4. Stavrou (1995) also proposes that the lower adjective kokino is within the NP. Her analysis differs from Alexiadou \& Wilder's (1998) in that she argues that to meyalo is found in the specifier of the projection that has as its head the definite determiner, thus manifesting agreement in definiteness.

5. In our discussion we do not include free relatives. For a recent overview of the Greek literature on this topic see Alexiadou \& Varlokosta (1996), and Philippaki-Warburton \& Spyropoulos (1996).

6. Cf. Jaeggli (1982), Anagnostopoulou (1994), Dobrovie-Sorin (1990) among many others. 
7. It should be noted that the conclusions reached in the two works are partially influenced by the fact that there are differences in judgements concerning quantifier variable binding data, an area where linguists working on Greek appear to disagree a lot. It would be very useful if Greek linguists tried to clarify this domain, as well as issues pertaining to Quantifier Scope and Superiority, as these are crucial tests for phrase-structure. We would like to point out that our experience with informants has led us to conclude that there is genuine variation among speakers with respect to WCO, Scope and Superiority judgements.

\section{References}

Abney, Steven. 1987. The English Noun Phrase in its Sentential Aspect. Ph. D. dissertation, MIT. Agouraki, Yoryia. 1990. "On the projection of maximal categories: the case of CP and FP in Modern Greek”. UCL Working Papers in Linguistics 2. 183-199.

Agouraki, Yoryia. 1991. "A Modern Greek complementizer and its significance for Universal Grammar." UCL Working Papers in Linguistics 3. 1-24.

Agouraki, Yoryia. 1993. Spec-Head Licensing: the Case of Foci, Clitic-constructions and Polarity Items: A Case Study of Modern Greek. Ph. D. dissertation, UCL.

Alexiadou, Artemis. 1997. Adverb Placement: A Case Study in Antisymmetric Syntax, Amsterdam: John Benjamins.

Alexiadou, Artemis. 1998. "On the structure of Greek relative clauses". Studies in Greek Linguistics 18. 15-29.

Alexiadou, Artemis. 1999a. “On the properties of some Greek word order patterns”. Studies in Greek Syntax. Kluwer Academic Publishers. 45-65.

Alexiadou, Artemis. 1999b. "On the licensing of possible subject positions in Romance and Greek”. Submitted for the Proceedings of the Deutsche Gesellschaft fuer Sprachwissenschaft [German Linguistic Association] Workshop Adding and Omitting. Amsterdam: John Benjamins.

Alexiadou, Artemis. 1999c. On the Syntax of Nominalization and Possession: Remarks on Patterns of Ergativity. Habilitationsschrift, Universität Potsdam.

Alexiadou, Artemis \& Elena Anagnostopoulou. 1995. "SVO and EPP in null subject languages and Germanic". FAS Papers in Linguistics 4. 1-21.

Alexiadou, Artemis \& Elena Anagnostopoulou. 1997. "Toward a uniform account of scrambling and clitic doubling”. In Werner Abraham \& Elly van Gelderen eds. German: Syntactic Problems- Problematic Syntax. Max Niemeyer Verlag. 142-161.

Alexiadou, Artemis \& Elena Anagnostopoulou. 1998a. "Paremetrizing AGR: word order, verbmovement and EPP-checking”. Natural Language and Linguistic Theory 16. 491-539.

Alexiadou, Artemis \& Elena Anagnostopoulou. 1998b. "Tests for unaccusativity in a language without tests for unaccusativity". In the Proceedings of the 3rd International Conference on Greek Linguistics. 23-31.

Alexiadou, Artemis \& Elena Anagnostopoulou. 1999a. "Raising without infinitives and the nature of agreement". To appear in the Proceedings of WCCFL 18. 
Alexiadou, Artemis \& Elena Anagnostopoulou. 1999b. "Non active morphology and the direction of transitivity alternations". Proceedings of NELS 29 (papers from the poster session). 27-40.

Alexiadou, Artemis \& Elena Anagnostopoulou. 1999c. "Clitic doubling and non-configurationality". To appear in the Proceedings of NELS 30 (papers from the poster session).

Alexiadou, Artemis \& Elena Anagnostopoulou. 2000. "Asymmetries in the distribution of clitics: the case of Greek restrictive relatives”. In Frits Beukema \& Marcel den Dikken eds. Clitics in the Languages of Europe. Amsterdam: John Benjamins. 47-70.

Alexiadou, Artemis, Geoffrey Horrocks \& Melita Stavrou eds. 1999. Studies in Greek Syntax. Dordrecht: Kluwer Academic Publishers.

Alexiadou, Artemis, Geoffrey Horrocks \& Melita Stavrou. 1999. "Introduction". Studies in Greek Syntax. Dordrecht: Kluwer Academic Publishers. 1-21.

Alexiadou, Artemis \& Melita Stavrou. 1997. "Crosslinguistic asymmetries in N-movement: a view from morphology”. ZAS Papers in Linguistics 8. 1-16.

Alexiadou, Artemis \& Melita Stavrou. 1998a. “On derived nominals in Greek”. In Brian Joseph, Geoffrey Horrocks \& Irene Philippaki-Warburton eds. Themes in Greek Linguistics II. Amsterdam: John Benjamins. 101-129.

Alexiadou, Artemis \& Melita Stavrou. 1998b. “(A)symmetries in DPs and clauses: evidence from derived nominals”. The Linguistic Review 15 .2-3. 257-276.

Alexiadou, Artemis \& Melita Stavrou. 1999. “Adjective-clitic combinations in the Greek DP”. To appear in the Proceedings of the Deutsche Gesellschaft fuer Sprachwissenschaft [German Linguistic Association] Workshop: Clitics. Amsterdam: John Benjamins.

Alexiadou, Artemis \& Spyridoula Varlokosta. 1996. "The syntactic and semantic properties of free relatives in Modern Greek”. ZAS Papers in Linguistics 5. 1-32.

Alexiadou, Artemis \& Chris Wilder. 1998. "Adjectival modification and multiple determiners”. In Artemis Alexiadou \& Chris Wilder eds. Possessors, Predicates and Movement in the DP, Amsterdam: John Benjamins. 303-332.

Alexopoulou, Theodora. 1999. The Syntax of Discourse Functions in Greek: A Non-configurational Approach. Ph. D. dissertation, University of Edinburgh.

Anagnostopoulou, Elena. 1994. Clitic Dependencies in Modern Greek, Ph.D. dissertation, Universität Salzburg.

Anagnostopoulou, Elena. 1997. "Clitic left dislocation and contrastive left dislocation". In Elena Anagnostopoulou, Henk van Riemsdijk \& Frans Zwarts eds. Materials on Left Dislocation. Amsterdam: John Benjamins. 151-192.

Anagnostopoulou, Elena. 1999a. “On experiencers". Studies in Greek Syntax. Dordrecht: Kluwer Academic Publishers. 67-93.

Anagnostopoulou, Elena. 1999b. On Double Object Alternations and Clitics. Ms., University of Crete. To be published Mouton de Gruyter.

Anagnostopoulou, Elena \& Martin Everaert. 1996. "How exceptional are nominative anaphors? A case study of Greek". In Lea Nash, George Tsoulas \& Annie Zribi-Hertz eds. Actes du deuxieme colloque Langues \& Grammaire 1995. 19-32. Paris.

Anagnostopoulou, Elena \& Martin Everaert. 1999. “Towards a more complete typology of anaphoric expressions”. Linguistic Inquiry 30. 97-119. 
Anagnostopoulou, Elena \& Anastasia Giannakidou. 1995. Clitics and prominence or why specificity is not enough". In Papers from the 31st Regional Meeting of the Chicago Linguistic Society 1996. Volume 2: The Parasession on Clitics: 1-14. University of Chicago. Anagnostopoulou, Elena, Henk van Riemsdjik \& Frans Zwarts. 1997. Material on Left Dislocation. Amsterdam: John Benjamins.

Androutsopoulou, Antonia. 1994. "The distribution of definite determiners and the syntax of Greek DPs". In Proceedings of CLS.

Aoun, Joseph. 1981. The Formal Nature of Anaphoric Relations. Ph.D. dissertation, MIT.

Aoun, Joseph. 1999. "Clitic doubled arguments”. In K. Johnson and I. Roberts eds. Beyond Principles and Parameters. Essays in Memory of Osvaldo Jaeggli. Dordrecht: Kluwer Academic Publishers. 13-42.

Baker, Mark. 1988. Incorporation: A Theory of Grammatical Function Changing. Chicago: Chicago University Press.

Baker, Mark. 1996. The Polysynthesis Parameter. Oxford: Oxford University Press.

Barss, Andrew \& Howard Lasnik. 1986. “A note on anaphora and double objects”. Linguistic Inquiry 17. 347-354.

Bianchi, V. 1995. Consequences of Antisymmetry for the Syntax of Headed Relative Clauses. Ph. D. dissertation, Scuola Normale Superiore Pisa.

Belletti, Adriana. 1990. Generalized Verb Movement: Aspects of Verb Syntax. Torino: Rosenberg \& Selier.

Belletti, Adriana \& Luigi Rizzi. 1988. "Psych-verbs and theta theory". Natural Language and Linguistic Theory 3. 291-352.

Bonet, Eulalia. 1991. Morphology After Syntax: Pronominal Clitics in the Romance Languages. $\mathrm{Ph}$. D. dissertation, MIT.

Bonet, Eulalia. 1994. “The person-case constraint: a morphological approach”. In Heidi Harley \& Collin Phillips eds. The Morphology-Syntax Connection. Cambridge, Mass.: MIT Press. 33-52.

Borer, Hagit. 1989. “Anaphoric AGR”. In Osvaldo Jaeggli \& Ken Safir eds. The Null Subject Parameter. Dordrecht: Kluwer Academic Publishers. 69-91.

Borer, Hagit. 1996. The Syntax of Pronominal Clitics. New York: Academic Press.

Cardinaletti, Anna \& Michal Starke. 1995. "The typology of structural deficiency: on the three grammatical classes”. ZASPIL 1.

Cardinaletti, Anna \& Ian Roberts. 1991. “Clause Structure and X-second”. Ms. University of Venice \& University of Bangor.

Catsimali, Georgia. 1990. Case in Modern Greek: Implications for Clause Structure. Ph.D. dissertation, University of Reading.

Chomsky, Noam. 1981. Lectures on Government and Binding. Dordrecht: Foris.

Chomsky, Noam. 1993. "A minimalist program for linguistic theory". In Kenneth Hale and S. J. Keyser eds. The View from Building 20. Cambridge, Mass.: MIT Press. 1-52.

Chomsky, Noam. 1995. The Minimalist Program. Cambridge, Mass.: MIT Press.

Chomsky, Noam. 1998. Minimalist inquiries: the framework. MITOPL 15.

Chomsky, Noam. 1999. Derivation by phase. MITWPL 18.

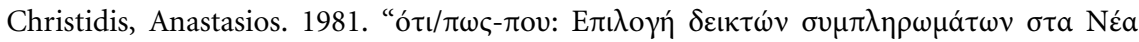

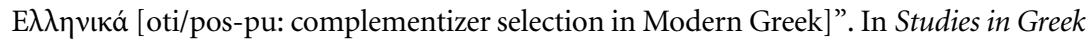
Linguistics 2. 113-179. 
Cinque, Guglielmo. 1990. Types of A-bar Dependencies. Cambridge, Mass.: MIT Press.

Cinque, Guglielmo. 1993. "On the evidence for partial N-Movement in the Romance DP".

University of Venice Working Papers in Linguistics 3.2. 21-40.

Cinque, Guglielmo. 1999. Adverbs and Functional Heads. Oxford: Oxford University Press.

Condoravdi, Cleo. 1989. "The Middle: where semantics and morphology meet". MIT Working Papers in Linguistics 11. 16-30.

Davidson, Donald. 1969. “On saying that”. In Donald Davidson and Jaakko Hintikka eds. Words and objections. Dordrecht: Reidel. 158-174.

Dimitriadis, Alexis. 1999. "On clitics, prepositions and case licensing in Standard and Macedonian Greek”. Studies in Greek Syntax. Kluwer Academic Publishers. 95-112.

Dobrovie-Sorin, Carmen. 1990. "Clitic doubling, Wh-movement and quantification in Romanian”. Linguistic Inquiry 21. 351-397.

Drachman, Gaberell. 1983. "Parameters and functions of clitic doubling in Modern Greek". Paper presented at the 4th Meeting on Greek Linguistics, University of Thessaloniki.

Drachman, Gaberell. 1991. “Clitic Placement”. Unpublished manuscript, Universität Salzburg. Drachman, Gaberell. 1994. "Verb movement and minimal clauses". Themes in Greek Linguistics. Amsterdam: John Benjamins. 45-52.

Drachman, Gaberell. 1997. "Some properties of clitics with special reference to Modern Greek". In Artemis Alexiadou \& T. Alan Hall eds. Studies on Universal Grammar and Typological Variation. Linguistik Aktuell Series 13. Amsterdam: John Benjamins. 219-248.

Drachman, Gaberell, Angeliki Malikouti-Drachman, Ioannis Fykias \& Sila Klidi. eds. 1997. Greek Linguistics. The Department of Linguistics, University of Salzburg.

Embick, David. 1998. Unaccusative Syntax and Voice Systems. Ms. MIT.

Enç, Mürvet. 1991. “The semantics of specificity”. Linguistic Inquiry 22. 1-25.

Everaert, Martin \& Elena Anagnostopoulou. 1997. "Thematic hierarchies and binding theory: evidence from Greek”. In F. Gorblin, D. Godard \& J.-M. Marandin eds. Empirical Issues in Formal Syntax and Semantics. Selected Papers from the Colloque de Syntaxe et de Sémantique de Paris (CSSP 1995), 43-59. Bern: Peter Lang AG, European Academic Publishers.

Fukui, Noki \& Margaret Speas. 1986. "Specifiers and projection”. MIT Working Papers 8. $128-172$.

Fykias, Ioannis. 1988. Aspekte der neugriechischen Syntax: eine rektions- und bindungstheoretische Untersuchung von Kasus-Mechanismen des Neugriechischen. Ph. D. dissertation. University of Salzburg.

Fykias, Ioannis. 1997. “The case system in Modern Greek: evidence from PPs”. In Gaberell Drachman et al. eds. Greek Linguistics II. 439-448.

Giannakidou, Anastasia. 1997. The Landscape of Polarity Items. Ph. D. dissertation, University of Groningen.

Ginzburg, Jonathan \& Dimitra Kolliakou. 1997. "Events and facts: the semantics of pu and oti clauses”. In Gaberell Drachman et al. eds. Greek Linguistics II. 459-470.

Grimshaw, Jane. 1990. Argument Structure. Cambridge, Mass.: MIT Press.

Hale, Kenneth. 1983. "Walpiri and the grammar of non-configurational languages". Natural Language and Linguistic Theory 1. 5-47.

Hegarty, Michael. 1992. "Familiar complements and their complementizers: on some determinants of A-locality”. Unpublished manuscript, University of Pennsylvania. 
Hegarty, Michael. 1999. "Clitic placement and the projection of functional categories". Studies in Greek Syntax. Kluwer Academic Publishers. 135-152.

Hornstein, Norbert. 1990. As Time Goes by: Tense and Universal Grammar. Cambridge, Mass.: MIT Press

Horrocks, Geoffrey. 1989. Clitics in Greek: Against a Head-Movement Analysis of Morphologysyntax Interaction. Ms., University of Cambridge \& University of Crete. Horrocks, Geoffrey. 1994. "Subjects and Configurationality". Journal of Linguistics 30. 81-109.

Horrocks, Geoffrey \& Melita Stavrou. 1987. "Bounding theory and Greek syntax: evidence for wh-movement in NP”. Journal of Linguistics 23. 79-108.

Hurtado, A. 1984. Clitic Chains. Ms. Simon Fraser.

Iatridou, Sabine. 1986. “An anaphor not bound in its governing category”. Linguistic Inquiry 17. 766-772.

Iatridou, Sabine. 1988. “Clitics, anaphors, and a problem of coindexation”. Linguistic Inquiry 19. 698-703.

Iatridou, Sabine. 1991. Clitics and Island Effects. Ms., MIT.

Iatridou, Sabine. 1993. "On nominative case assignment and a few related things". MIT Working Papers in Linguistics 19. 175-198.

Jaeggli, Osvaldo. 1982. Topics in Romance Syntax. Dordrecht: Foris.

Jaeggli, Osvaldo. 1986. "Three issues in the theory of clitics: case, doubled NPs and extraction" In Hagit Borer ed. Syntax and Semantics 19: The Syntax of Pronominal Clitics. New York: Academic Press. 15-42.

Joseph, Brian. 1983. The Synchrony and Diachrony of the Balkan Infinitive. A Study in Areal, General, and Historical Linguistics. Cambridge: Cambridge University Press.

Joseph, Brian. 1988. "Pronominal Affixes in Modern Greek. The case against clisis". CLS.24. 203-215.

Joseph, Brian. 1994. “On weak subjects and pro-drop in Greek”. In Irene PhilippakiWarburton, Katerina Nicolaidis \& Maria Sifianou. eds. Themes in Greek Linguistics. Amsterdam: John Benjamins. 21-32.

Joseph, Brian \& Jane Smirniotopoulos. 1993. “The morphosyntax of the Modern Greek verb as morphology and not syntax". Linguistic Inquiry 24. 388-398.

Kakouriotis, Thanos. 1993. Argument Relations. Athens: Seagull.

Karanassios, George. 1992. Syntaxe Comparée du Groupe Nominal en Grec et dans d'autres Langues. Doctorat d'état, Université de Paris VIII, Vincennes.

Kayne, Richard. 1975. French Syntax. Cambridge, Mass.: MIT Press.

Kayne, Richard. 1989. "Null Subjects and Clitic Climbing”. In Osvaldo Jaeggli and Ken Safir eds. The Null Subject Parameter. Dordrecht: Kluwer Academic Publishers. 239-261.

Kayne, Richard. 1991. "Romance clitics, verb movement, and PRO". Linguistic Inquiry 22. 647-686.

Kayne, Richard. 1994. The Antisymmetry of Syntax. Cambridge, Mass.: MIT Press.

Kiparsky, Paul \& Carol Kiparsky. 1971. "Fact". In D. Steinberg and L. Jacobovits eds. Semantics. Cambridge: Cambridge University Press. 345-369.

Kiss, Katalin. 1987. Configurationality in Hungarian. Dordrecht: Reidel.

Kiss, Katalin. 1996. The Focus Operator and Information Focus. Ms. 


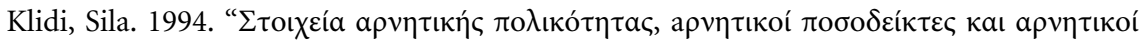

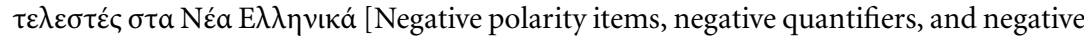
operators in Modern Greek]". Studies in Greek Linguistics 15. 451-461.

Kolliakou, Dimitra. 1997. Clitic Climbing in the Noun Phrase. Ms., University of Groningen. Koopman, Hilda \& Dominique Sportiche. 1989. "Pronouns, logical variables and logophoricity in Abe”. Linguistic Inquiry 20. 555-588.

Larson, Richard. 1988. "On the double object construction”. Linguistic Inquiry 19. 335-391. Levin, Beth \& Malka Rappaport. 1995. Unaccusativity. Cambridge, Mass.: MIT Press.

Mackridge, Peter. 1985. The Modern Greek Language. Oxford: Oxford University Press.

Mahajan, Anoop. 1990. The A/A Distinction and Movement Theory. Ph. D. dissertation, MIT. Marantz, Alec. 1991. "Case and licensing”. Proceedings of ESCOL. 234-253.

Marantz, Alec. 1997. "No escape from syntax: Don't try a morphological analysis in the privacy of your own lexicon". Ms., MIT.

Markantonatou, Stella. 1992. The Syntax of Modern Greek Noun Phrases with a Derived Nominal Head. Ph. D. dissertation, University of Essex.

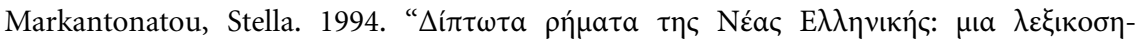

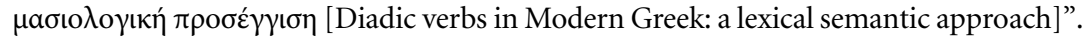
Studies in Greek Linguistics 15. 362-371.

Mouma, Evangelia. 1993. “On some properties of DPs in Modern Greek”. UCL Working Papers in Linguistics. 5: 75-102.

Nespor, Marina \& Irene Vogel. 1986. Prosodic Phonology. Dordrecht: Foris.

Ormazabal, Javier \& Juan Romero. 1998. "On the Syntactic Nature of the me-lui and the Person Case Constraint”. Ms., University Basque Country (EHU)/Basque Center for Language Research (LEHIA) and MIT.

Ouhalla, Jamal. 1988. The Syntax of Head Movement. Ph. D. dissertation, UCL.

Pesetsky, David. 1987. "Wh-in-situ: movement and unselective binding”. In Eric Reuland, and Alice ter Meulen eds. The Representation of (In)definiteness. Cambridge, MA: MIT Press. 98-129.

Pesetsky, David. 1995. Zero Syntax. Cambridge, Mass.: MIT Press.

Perlmutter, David. 1971. Deep and Surface Structure Constraints in Syntax. New York: Rinehart \& Winston Inc.

(Philippaki)-Warburton, Irene. 1977. "Modern Greek clitic pronouns and the 'surface structure constraints' hypothesis". Journal of Linguistics 13. 259-281.

Philippaki-Warburton, Irene. 1985. "Word order in Modern Greek". Transactions of the Philological Society 2. 113-143.

Philippaki-Warburton, Irene. 1987. "The theory of empty categories and the Pro-drop parameter in Modern Greek”. Journal of Linguistics 23. 289-318.

Philippaki-Warburton, Irene. 1989. "Subject in English and in Greek". Proceedings of the 3rd Symposium on the Description and/or Comparison of English and Greek. Department of English, Aristotle University of Thessaloniki. 11-32.

Philippaki-Warburton, Irene. 1994a. "The subjunctive mood and the syntactic status of the particle na in Modern Greek". Folia Linguistica 28. 297-328.

Philippaki-Warburton, Irene. 1994b. "V-movement and clitics in Modern Greek". Themes in Greek Linguistics. Amsterdam: John Benjamins. 53-60. 
Philippaki-Warburton, Irene. 1998. "Functional categories and Modern Greek syntax". The Linguistic Review 15. 159-186.

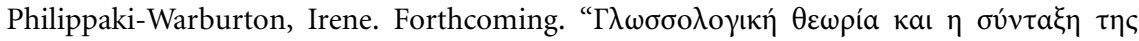

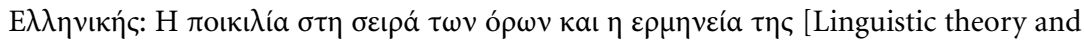
Greek syntax: Word order variation and its interpretation]". To appear in the Proceedings of the 4th International Conference on Greek Linguistics. Nicosia, Cyprus.

Philippaki-Warburton, Irene \& Georgia Catsimali. 1999. On Control in Greek. Studies in Greek Syntax. Dordrecht: Kluwer Academic Publishers. 153-168.

Philippaki-Warburton, Irene, Katerina Nicolaidis \& Maria Sifianou. eds. 1994. Themes in Greek Linguistics I. Amsterdam: John Benjamins.

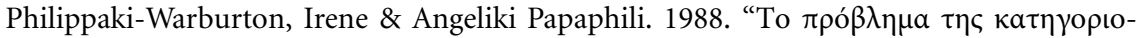

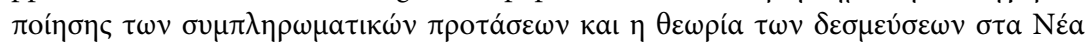
E $\lambda \lambda \eta v ı \kappa a ́$ [Categorisation of Modern Greek complement clauses and bounding theory]". Studies in Greek Linguistics 9. 293-314.

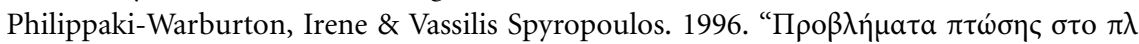

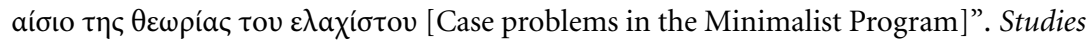
in Greek Linguistics 17. 261-275.

Philippaki-Warburton, Irene \& Vassilis Spyropoulos. 1999a. "On the boundaries of inflection and syntax: Greek pronominal clitics and particles”. In Booij, G \& J. van Marle The Yearbook of Morphology 1998. Dordrecht: Kluwer Academic Publishers 45-72.

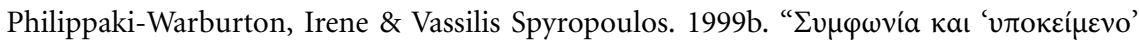

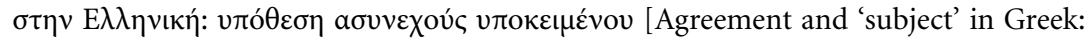
discontinuous subject hypothesis]". Proceedings of the 3rd International Conference on the Greek Language. Athens. 303-314.

Philippaki-Warburton, Irene \& Ioannis Veloudis. 1984. "The Subjunctive in complement clauses". Studies in Greek Linguistics 5. 87-104.

Picallo, Maria-Carmen. 1991. "Nominals and Nominalizations in Catalan". Probus 3. 279-316.

Pollock, Jean-Yves. 1989. "Verb movement, UG and the structure of IP”. Linguistic Inquiry 20. 365- 424.

Reinhart, Tanya \& Eric Reuland. 1993. "Reflexivity”. Linguistic Inquiry 24. 657-720.

Richards, Norvin. 1997. What moves where in what language. Ph. D. dissertation, MIT.

Ritter, Elisabeth. 1995. "On the syntactic category of pronouns and agreement”. Natural Language and Linguistic Theory 13. 405-443.

Rivas, A. 1977. A Theory of Clitics. Ph. D. dissertation, MIT.

Rivero, Maria-Luisa. 1992. "Adverb incorporation and the syntax of adverbs in Modern Greek". Linguistics and Philosophy 15. 289-331.

Rivero, Maria-Luisa. 1994. "Verb movement and the structure of IP in the languages of the Balkans". Natural Language and Linguistic Theory 12. 63-120.

Rivero, Maria-Luisa \& Arhonto Terzi. 1995. "Imperatives, V-movement and logical mood". Journal of Linguistics 33. 301-332.

Rizzi, Luigi. 1990. Relativized Minimality. Cambridge, Mass.: MIT Press.

Ralli, Angeliki. 1994. "Feature representations and feature-passing operations: the case of Greek nominal inflection". In the Proceedings of the 8th International Symposium on 
English \& Greek, School of English Dept of Theoretical \& Applied Linguistics. Aristotle University of Thessaloniki.

Ralli, Angeliki. 1997. "Inflectional features and the morphological component hypothesis". GLOW Newsletter 38. 46-47.

Roussou, Anna. 1991. "Nominalized clauses in the syntax of Modern Greek". UCL Working Papers in Linguistics 3. 77-100.

Roussou, Anna. 1992. "Factive complements and Wh-movement in Modern Greek". UCL Working Papers in Linguistics 4. 125-147.

Roussou, Anna. 1993. "Factivity, factive islands and the that-t filter". Proceedings of Console 1.

Roussou, Anna. 1999. "Modals and the Subjunctive". Studies in Greek Syntax. Dordrecht: Kluwer Academic Publishers. 169-183.

Safir, Ken. 1985. Syntactic Chains, Cambridge: Cambridge University Press.

Schneider-Zioga, Patricia. 1993. The Syntax of Clitic Doubling in Modern Greek. Ph.D. dissertation, USC, Los Angeles, California.

Sioupi, Athina. 1997. "Middle contructions in Modern Greek and their equivalents in German”. In Gaberell Drachman et al. eds. Greek Linguistics 1995 . 599-608.

Smirniotopoulos, Jane. 1992. Lexical Passives in Greek. Garland Publishers.

Smirniotopoulos, Jane \& Brian Joseph. 1998. "Incorporation and compounding in Modern Greek”. Journal of Linguistics 34. 447-488.

Sportiche, Dominique. 1992. "Clitic constructions”. Unpublished manuscript, UCLA.

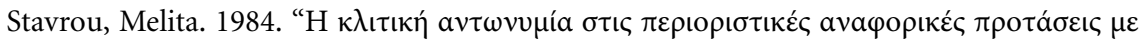

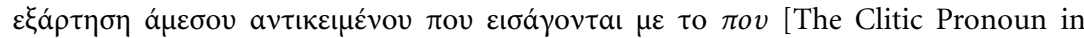
$p u$-restrictive relatives that contain a direct object dependency]", Studies in Greek Linguistics 5. 121-136.

Stavrou, Melita. 1995. "Epexegesis vs. apposition”. Scientific Yearbook of the Classics Dept. Aristotle University of Thessaloniki.

Stavrou, Melita. 1999. "The Position and serialization of APs in the DP: Evidence from Greek". Studies in Greek Syntax. Dordrecht: Kluwer Academic Publishers. 201-225.

Stotzer, Judith. 1976. Clitics in Spanish. Ph. D. dissertation, UCLA.

Szabolsci, Anna. 1983. "The possessor that ran away from home". The Linguistic Review 3. 89-102.

Taraldsen, Knut. 1995. "On agreement and nominative objects in Icelandic". In Hubert Haider, Sue Olsen and Sten Vikner eds. Studies in Comparative Germanic Syntax. Dordrecht: Kluwer Academic Publishers. 307-327.

Terzi, Arhonto. 1992. PRO in Finite Clauses: a Study of the Inflectional Heads of the Balkan Languages. Ph. D. dissertation, CUNY.

Terzi, Arhonto. 1996. "The Linear Correspondence Axiom and the adjunction site of clitics". In Anna- Maria Di Sciullo ed., Configurations. Cascadilla Press. 185-199.

Terzi, Arhonto. 1999a. "Cypriot Greek clitics and their positioning restrictions". Studies in Greek Syntax. Dordrecht: Kluwer Academic Publishers. 227-240.

Terzi, Arhonto. 1999b. "Clitic combinations, their hosts and their ordering". Natural Language and Linguistic Theory 17. 85-121.

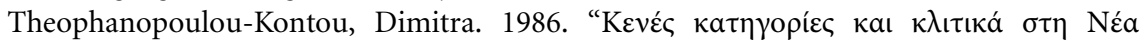

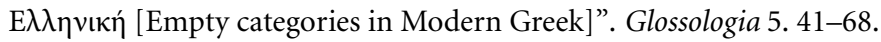




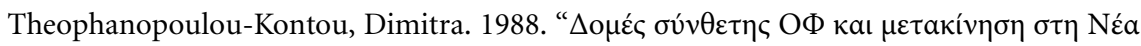

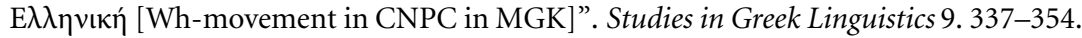
Theophanopoulou-Kontou, Dimitra. 1994. "Transformational Grammar and Modern Greek syntax: an overview and some problematic cases". Themes in Greek Linguistics. Amsterdam: John Benjamins. 11-20.

Theophanopoulou-Kontou, Dimitra. 1997. "Locative prepositions and case marking in Modern Greek”. In Gaberell Drachman et al. eds. Greek Linguistics 1995. 619- 630.

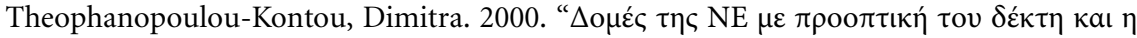

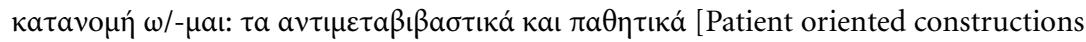
in Modern Greek and the o/-me alternation: anticausative and passives]". Studies in Greek Linguistics 20. 146-157.

Torrego, Ester \& Juan Uriagereka. 1993. "Indicative dependents”. Ms. University of Mass. \& UMD.

Tsimpli, Ianthi-Maria. 1989. “On the properties of the passive affix in Modern Greek”. UCL Working Papers 1. 235-260.

Tsimpli, Ianthi-Maria. 1990. “The clause structure and word order of Modern Greek”. UCL Working Papers in Linguistics 2. 226-255.

Tsimpli, Ianthi-Maria. 1995. "Focussing in Modern Greek". In Katalin Kiss ed. Discourse Configurational Languages. Oxford: Oxford University Press.

Tsimpli, Ianthi-Maria. 1999. "Null operators, clitics and identification". Studies in Greek Syntax. Dordrecht: Kluwer Academic Publishers. 214-262.

Tsoulas, George. 1993. "Remarks on the structure and the interpretation of na-clauses". Studies in Greek Linguistics 14. 196-207.

Vallduvi, Enric. 1992. “A preverbal landing site for quantificational operators”. Catalan Working Papers 2. 319-343.

Varlokosta, Spyridoula. 1994. Issues on Modern Greek Sentential Complementation, Ph.D. dissertation, University of Maryland.

Varlokosta, Spyridoula \& Norbert Hornstein. 1993. "A bound pronoun in Modern Greek". Natural Language and Linguistic Theory 11. 175-195.

Vergnaud, R. 1974. French Relative Clauses. Ph.D dissertation, MIT.

Xydopoulos, George. 1996. Tense, Aspect and Adverbials in Modern Greek. Ph. D. dissertation, UCL.

Zanuttini, Raffaela. 1991. Syntactic Properties of Sentential Negation: A Comparative Study of Romance Languages. Ph. D. dissertation, University of Pennsylvania.

Zubizarreta, Maria-Luisa. 1998. Prosody, Focus and Word Order. Cambridge, Mass.: MIT Press.

\section{$\Pi \varepsilon \rho i ́ \lambda \eta \psi \eta$}

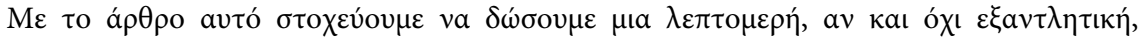

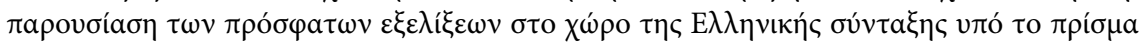

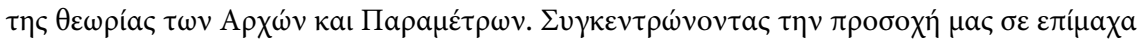

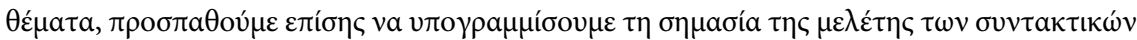

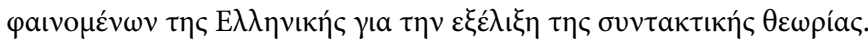

